\title{
El colegio San Francisco Javier de Mérida, modelo educativo para una ciudad pequeña colonial
}

The school San Francisco Javier de Mérida, educational model for a small colonial city

José del Rey Fajardo SJ*

Resumen: El artículo se compone de dos partes fundamentales. La primera constituye una introducción a la denominada paideia jesuítica: la "formación integral". El código por el que se rigieron todas las instituciones educativas se denominó Ratio Studiorum, es decir, un método eficaz, bien estructurado, cuidadoso de los mecanismos de adquisición de conocimientos, adaptado a las necesidades de su tiempo. Por ello entendieron que el compromiso con "el bien común" debía ser expresión de la cultura, la urbanidad, la civilidad, la conversación y, en definitiva, del diseño de un hombre honesto. La segunda parte estudia el colegio San Francisco Javier de Mérida (Venezuela), arquetipo del "colegio indiano" que constituye una experiencia revolucionaria porque dotó de la experiencia mínima requerida a las juventudes que se levantaban lejos de los centros de poder en ciudades con demografía inferior a los 500 habitantes. Fue una educación totalmente gratuita y pública y además les garantizaba el ingreso a la universidad y el desenvolvimiento correcto en la sociedad. La estructura del "colegio indiano" descansaba generalmente sobre cuatro personas. El Rector, responsable local de la vida escolar por él presidida. El Profesor de Gramática que atendía permanentemente la marcha de las aulas. El Procurador del colegio que iría adquiriendo dimensiones desorbitadas por los capitales y riesgos que debía correr para generar los productos y posteriormente mercadearlos. Y el Prefecto de Iglesia, encargado del fomento de los ministerios encaminados a la práctica de las virtudes cristianas no sólo de los alumnos sino también de los feligreses que acudían al templo jesuítico. Después de dedicar un análisis de lo que debía ser el profesor se estudia en detalla el pensum, los textos utilizados, el ingreso y promo-

\footnotetext{
* Academia Nacional de la Historia. Caracas. E-mail: jfajardo1934@gmail.com
} 
ción de los alumnos, el calendario escolar, las composiciones, los actos públicos, el teatro y la Academia.

Palabras claves: Paideia, Ratio Studiorum, "colegio indiano", organización escolar.

\begin{abstract}
The article consists of two fundamental parts. The first is an introduction to the so-called Jesuit paideia: "integral formation". The code by which all educational institutions were governed was called Ratio Studiorum, that is to say, an efficient, well structured, careful method of the mechanisms of acquisition of knowledge, adapted to the necessities of his time. Therefore, they understood that the commitment to "the common good" should be an expression of culture, civility, civility, conversation and, ultimately, the design of an honest man. The second part studies the school San Francisco Javier de Merida (Venezuela), archetype of the "Indian school" that constitutes a revolutionary experience because it provided the minimum experience required to the youths that rose far from the centers of power in cities with lower demography To the 500 inhabitants. It was a totally free and public education and also guaranteed the entrance to the university and the correct development in society. The structure of the "Indian college" usually rested on four people. The Rector, responsible local of the school life that he presided over. The grammar teacher who attended permanently the march of the classrooms. The public prosecutor of the school that would acquire exorbitant dimensions by the capitals and risks that had to run to generate the products and later to market them. And the Prefect of the Church, responsible for the promotion of ministries aimed at the practice of the Christian virtues not only of the students but also of the parishioners who came to the Jesuit temple. After dedicating an analysis of what the teacher should be, we study in detail the pensum, the texts used, the entrance and promotion of the students, the school calendar, the compositions, the public events, the theater and the Academy.
\end{abstract}

Key words: Paideia, Ratio Studiorum, "Indian school", school organization.

Recibido: 6 de setiembre de 2016

Evaluado: 28 de noviembre de 2016 


\section{Introducción}

En el caso del continente colombino, la acción de los seguidores de Ignacio de Loyola en la educación de las juventudes americanas, su influjo en la formación del pensamiento criollo, su cooperación a la gestación de economías creativas y abiertas, su inserción en la historia de los pueblos aborígenes esparcidos en las que se consideraron zonas marginales de las tierras descubiertas por Colón, su inspiración para plasmar en el arte un barroco criollizado y su ingente producción científica y literaria sobre un mundo nuevo en hombres y libertad, consagran y definen el aporte de la Orden de Ignacio de Loyola a la biografía de este gran Continente.

En los últimos tiempos ha venido llamando la atención de los investigadores el estudio de lo "local" dentro del horizonte de la globalización. En la época colonial las ciudades, sobre todo las provincianas, supieron asumir su papel protagónico ya que, como diría Francisco González Cruz, estamos ante la localidad global pues el mundo es de todos, pero cada una de las partes de ese todo, conservan sus rasgos . En una palabra, los jesuitas se alucinaron por contribuir al "bien común" con el tiempo, el talento y el esfuerzo.

Todavía más, aquellos proscritos expatriados en los Estados Pontificios se constituyeron el "centro más denso de todo el americanismo europeo" y así se construyeron los fundamentos del tránsito de la conciencia criolla al nacionalismo emergente. De esta suerte se abrieron nuevos caminos para la historia natural, la geografía, la historia e incluso para incursionar la filosofía de la historia ${ }^{3}$ y así se levantaron las bases para los estudios científicos de las realidades naturales, sociales e históricas de América elaboradas desde el exilio ${ }^{4}$.

Para este estudio hemos elegido como arquetipo conceptual al Colegio San Francisco Javier de Mérida por dos razones. La primera, porque su biografía se extiende desde el 14 de mayo de $1628^{5}$ y su acción se prolongaría hasta 1767 fecha en que el rey Carlos III expulsó a los miembros de la Compañía de Jesús de todos sus dominios. En consecuencia estamos ante una institución educativa que responde plenamente a la primera estancia de los jesuitas en América. En segundo término, porque consideramos que dicha institución educativa es -a nuestro juicio- la que hasta el presente ha sido el mejor estudiada ${ }^{6}$.

\section{El marco histórico y conceptual.}

La obra de la Compañía de Jesús, como la de cualquier organización multinacional que posea cuatro siglos de historia, es la biografía de un ideal traducido en proyectos que fueron gestados por hombres y mentalidades muy diversas y llevados a cabo en muy diferentes épocas, lugares y situaciones.

\footnotetext{
1 González Cruz, 2001.

2 Batllori, 1966: 590.

3 Ibíd., 1982.

4 Ibíd., 1966.

5 Mercado, 1957: 7.

6 Samudio, Del Rey Fajardo y Briceño Jauregui, 2003.
} 
$\mathrm{Al}$ estallar la reforma protestante tanto Roma como Lutero detectan la necesidad de la cristianización de las masas y la espiritualización del sentimiento religioso ${ }^{7}$. Por ello ambas iglesias tratan de renovar las obsoletas estructuras medievales así como las actitudes religiosas generadas por el cansancio de una religiosidad anquilosada. Este esfuerzo restaurador les hace buscar a las dos Reformas los caminos de la modernidad ${ }^{8}$.

Y la Compañía de Jesús que antes era significada como el símbolo de la reacción conservadora pasa a ser considerada ahora como la imagen de la modernidad dentro de la Iglesia católica por su eficiente organización, su sistema pedagógico, por su red de colegios y universidades, por sus originales métodos misioneros y por su búsqueda de las masas en toda Europa.

Además tras la ruptura de la unidad religiosa de la Cristiandad se impone la era de la "Confesionalización" en donde las confesiones luchan por generar una nueva identidad no sólo en sus instituciones sino también en los modelos de comportamiento y en las prácticas religiosas ${ }^{9}$ porque de ello depende su nueva biografía.

A partir del Renacimiento lo religioso, cultural, social y político se invaden mutuamente y es la autoridad estatal la que pretende imponer su autoridad política sobre la base de la confesionalización. Y para ello recurre al concepto de "disciplinamiento social" requisito imprescindible sobre el que se construirá el Estado absoluto de la época moderna ${ }^{10}$. El ordenamiento religioso se vincula al político y al social y tiene como objetivo la uniformización de las conductas con rituales y símbolos comunes a la Iglesia y al Estado.

En este contexto la Compañía de Jesús asumió con visión el reto transformador de la educación. En efecto, la "Misión educación" es una identidad adquirida más allá del tiempo en que se define el carisma y la misión delineadas por las primeras Constituciones de la Compañía de Jesús, redactadas por el maestro parisiense Iñigo de Loyola. Este hecho convirtió a los jesuitas en la primera orden religiosa que se consagró a la educación media y superior dentro de la Iglesia Católica ${ }^{11}$.

La trascendencia de esta decisión fue tan fundamental que la Orden "enseñante" crita, es decir, de la "publicística", inigualable palestra intelectual para la sociedad del conocimiento ${ }^{13}$.

Los primeros jesuitas captaron rápidamente la ruptura creciente que se establecía entre las instituciones educativas, sus métodos y sus maestros y por otra parte la presión de las corrientes renovadoras que necesitaban garantizar un status social emergente a las nuevas sociedades. Y así descubrieron la validez que asumía en los nacientes Estados

\footnotetext{
7 Delumeau, 1979: 247. Citado por Borromeo, S/f [1991]: 327.

8 Reinhard, 1977: 226-252. Citado por Borromeo, S/f [1991]: 327.

9 Ibís., 1981: 165-189.

10 Schulze, 1987: 265-302. Citado por Borromeo, S/f [1991]: 328.

11 Para el proceso de evolución conceptual de Ignacio y de su Orden: ver Luckas, 1961. Ver la bula Regimini militantis Ecclesiae, 27 de septiembre de 1540.

12 Leturia, 1940: 350-382.

13 Sommervogel, 1890-1932.
} 
nacionales el cultivo del talento colectivo de innovación y su capitalización intelectual, su organización institucional y el éxito internacional que ello conllevaba.

La sociedad europea del XVI vivió una intensa aceleración en el movimiento que supuso la transición de una cultura oral a la escrita en el marco de la comercialización del libro impreso y en la demanda de escolarización para satisfacer las exigencias de las nuevas clases medias emergentes.

Así no es de extrañar que muchos príncipes, obispos, municipalidades y hombres de poder se apresuraran a buscar a los jesuitas como hombres bien formados, consagrados, seguros, competentes para sus respectivas jurisdicciones.

De esta forma se convirtieron los jesuitas en los regentes de la instrucción de la juventud europea y americana y ello los situó en las encrucijadas de la historia civil y la religiosa. Todavía más, los conflictos religioso-políticos de la Europa de la fe les haría asumir la tarea de formar a una proporción notable del clero secular europeo: alemán, húngaro, griego e inglés.

Por otra parte, el código de enseñanza universal para los colegios de la Compañía de Jesús, la denominada Ratio Studiorum ${ }^{14}$, publicada en 1599 -final del gran siglo de las Reformas- conllevaba en su interior una historia de medio siglo de intuiciones, esfuerzos, ensayos, experiencias, errores y revisiones que hicieron posible el edificio de la paideia jesuítica en todo el mundo ${ }^{15}$.

Además se inscribe en el desafío de respetar las aspiraciones de los particularismos de las ciudades renacentistas frente a las exigencias de los poderes nacionales empeñados en dar una respuesta "a la demanda universal de una formación que correspondiera a la racionalidad económica, jurídica, social y cultural" ${ }^{16}$.

Luce Giard inicia su visión sobre el aporte de los jesuitas al Renacimiento con lo que él denomina "el deber de la inteligencia" ${ }^{17}$, que consiste en enseñar y crear ciencia. Y en tal sentido cita la opinión de William Ashworth, quien afirma: "Se podría avanzar que la Compañía de Jesús fue antes que la Academia del Cimento o la Royal Society, la primera verdadera sociedad científica". También es verdad que más adelante tamiza su afirmación al mostrar sus reservas en la parte de innovación visible en la producción científica de la Compañía de Jesús en el siglo XVII porque los jesuitas se convirtieron en muy eclécticos y porque durante mucho tiempo se adhirieron a una "vista emblemática de la naturaleza" ${ }^{18}$.

Pero, antes de entrar en la materia de los saberes es necesario hacer referencia a un presupuesto imprescindible para entender las bases sobre las que se fundamentó el "deber de la inteligencia".

\footnotetext{
14 Para los textos de la Ratio Studiorum nos remitimos a: Lukacs, I, 1965; II, 1974; III, 1974; IV, 1981; V, 1986; VI, 1986; VII, 1992). En castellano: Del Rey Fajardo, 1995: 197-286. En francés: Demoustier y Julia, 1997. En alemán: Pachtler, 1887-1894. Sobre la Ratio nos permitimos sugerir: Charmot, 1952. Dainville, 1978. Codina Mir, 1968. Giard y Vaucelles, 1996. Batllori, 1993: 57-74.

15 Charmot, 1952: 367-394.

16 Demoustier, 1997: 12-13.

17 Giard, 1995: XI-LXXIX.

18 Ibíd.: XXV.
} 
El escritor norteamericano O'Malley no duda en afirmar que a través de los colegios los ignacianos adquirieron un compromiso con las ciudades en las que se insertaban. Por ello entendieron que "el bien común" debía ser expresión de la cultura, la urbanidad, la civilidad, la conversación y, en definitiva, del diseño de un hombre honesto. Bebieron esta inspiración en la tradición de la formación para el bien de la ciudad que nace con Isócrates en Atenas y que se incrustó en el corazón de los humanistas del Renacimiento. Los clásicos encontraron un excelente escenario en los colegios jesuíticos y fueron enseñados "no simplemente como modelos de vida sino también como fuentes de inspiración ética"

El descubrimiento del "capital humano" prendió como fuego en las nuevas sociedades renacentistas y de esa forma legitimó su demanda.

Todo este gigantesco esfuerzo desembocó en un modelo pedagógico experimentado en el mundo conocido, y al decir de Luce Giard sustentado "en un método eficaz, bien estructurado, cuidadoso de los mecanismos de adquisición de conocimientos, adaptado a las necesidades de su tiempo" 20 todo lo cual avaló el ideal de intelectualidad que acompañó a la primera Compañía de Jesús.

De esta forma los ignacianos pronto emprendieron el camino de la nueva ciencia y por ello se convirtieron en miembros activos de la República de las letras, de las artes y de las ciencias e hicieron acto de presencia como una empresa de "capitalización intelectual" y de organización institucional, conducida a escala internacional ${ }^{21}$.

Y como estatuye Roland Barthes la Ratio Studiorum de los jesuitas consagra la preponderancia de las humanidades y de la retórica latina en la educación de las juventudes. Su fuerza formativa la deriva de la ideología que legaliza, la "identidad entre una disciplina escolar, una disciplina de pensamiento y una disciplina de lenguaje",22.

\section{La República de las Letras y la promoción de las provincias}

En las Provincias americanas hispanas de la Compañía de Jesús, sólo ciudades como México o Lima podían aspirar a disponer de hombres y medios para poder llevar adelante el genuino ideal de la formación ignaciana. En un segundo grado se colocarían Córdoba, Quito, Santa Fe y otras. Y en el resto del continente se interponían grandes espacios en los que pequeñas ciudades pugnaban por adquirir identidad a la vez que levantaban lentamente su estructura institucional como parte de la maquinaria administrativa de la monarquía hispana.

Si adaptar la "Manzana jesuítica" en Bogotá a los grandes ideales de la Compañía de Jesús supuso un gran esfuerzo de imaginación pensamos que todavía fue más exigente traducir ese mensaje a las pequeñas ciudades provincianas que iniciaban su biografía municipal en medio de tantas dificultades.

La función psíquica exige para poder desarrollarse sustancia y promesas, es decir, arquetipos de identificación. Por ello, el jesuita americano -lo mismo que el euro-

\footnotetext{
19 O`Mallet, 2007: 28.

20 Giard, 1995 : LVI.

21 Ibíd.: XIII.

22 Barthes, 1974: 37.
} 
peo, el africano o el asiático- necesitaban encontrar en su alma Mater una herencia cultural que les hiciera habitantes de una historia y partícipes de una sociedad, para de esta forma sentirse actores en una red de relaciones a partir de las cuales pudieran elaborar comportamientos en respuesta a problemas existenciales. De esta manera, cada hijo de San Ignacio, cada colegio, cada rincón misional, cada hacienda reiteraba un modelo creador que invitaba no sólo a la imitación sino al riesgo de la superación.

El colegio indiano constituye una experiencia revolucionaria porque dotó de la experiencia mínima requerida a las juventudes que se levantaban lejos de los centros de poder en ciudades con demografía inferior a los 500 habitantes. Fue una educación totalmente gratuita y pública y además les garantizaba el ingreso a la universidad.

Dada la amplitud del tema ${ }^{23}$ nos restringiremos a las siguientes reflexiones:

La primera: Con la apertura de la Facultad de Lenguas el $1^{\circ}$ de enero de $1605^{24}$ en la capital neogranadina los jesuitas iniciaron un modelo educativo que se extendería por toda la geografía nacional. Al mediar el siglo XVII, los ignacianos se habían apostado en los enclaves que consideraban vitales para su acción en el Nuevo Reino. Habían asegurado la ruta del río Magdalena con puntos terminales de Cartagena y Bogotá en 1604 y los intermedios de Honda en 1620 y Mompós en 1643. También abriría hacia el oriente dos rutas estratégicas: la búsqueda de territorio venezolano y el insular de Santo Domingo con la apertura de Tunja en 1611, Pamplona en 1625 y Mérida en 1628. Y hacia la gran provincia de Guayana y el Atlántico establecerían el camino de Chita en 1625 y llegarían hasta Santo Tomé de Guayana en 1646. Las vías del sur hacia Quito se instauraría con la fundación de Popayán en $1640^{25}$. En el siglo XVIII se expandiría a Pasto en $1712^{26}$, a Antioquia en $1727^{27}$ y en 1745 a Buga ${ }^{28}$.

La segunda: el método no sólo garantizaba para cualificar en las letras a las juventudes provincianas y prepararlas para los estudios superiores sino también para hacerlas partícipes de las redes educativas internacionales que la compañía de Jesús movía en todo el mundo. De ahí la importancia que asumió el bilingüismo: la lengua latina como vehículo internacional para insertarse en la ciencia y la cultura; la castellana como expresión genuina de identidad con el imperio y la nación.

El estudio de la lengua latina no sólo abrió los caminos para el emplear el castellano sino para mejorarlo pulirlo. En última instancia, en esos tiempos, la teoría de la poética y de la retórica hispana se fueron distanciando muy lentamente de sus modelos latinos. Y por ello estatuye Osorio que "la teoría sobre lo bello, la versificación, los géneros literarios y, en general, lo que ahora llamamos teoría y preceptiva literarias,

\footnotetext{
23 Del rey Fajardo, 2010.

24 Sobre este tema, véase: Pacheco, 1991: 77-173. Del Rey Fajardo, s/f [2001]. Ibíd., 2002. Todavía sigue siendo un estudio clásico Rivas Sacconi, 1977.

25 Pacheco, 1959. Véase el tomo I.

26 Ibíd., 1962, II: 32.

27 Ibíd., 1989, III: 40.

28 Ibíd.: 52.
} 
dependió, más que en otras lenguas romances, de la respectiva poética y retórica latinas" 29 .

La tercera: con la enseñanza de la Retórica organizaron los jesuitas en la Nueva Granada la denominada "República de las Letras" pues, fuera de las ciencias, fue esta disciplina la que constituyó el único prestigio social e intelectual hasta mediados del siglo XVIII.

Este proyecto literario constituyó la base de la formación de innumerables generaciones del Nuevo Reino (1605-1767). Y casi nos atreveríamos a afirmar que la actual identidad cultural y lingüística del colombiano bebe sus orígenes en la fina retórica aprendida en la Facultad de Lenguas y en los diversos centros humanísticos que poblaron la Tierra Firme.

La cuarta: hoy todavía constituye un interrogante el aporte de la República de las Letras jesuíticas a la cultura neogranadina. Pero ¿cómo explicar la calidad de la oratoria civil y sagrada, la historia, la literatura espiritual y profana, la poesía, el teatro y otros muchos espacios literarios que la investigación irá apreciando en el camino?

En el campo netamente jesuítico debemos señalar que en los primeros 50 años de presencia ignaciana ya había surgido la primera generación de jesuitas neogranadinos que abandonaban las enseñanzas del clasicismo literario para adoptar las nuevas corrientes del gusto culterano. Nos referimos a los PP. Lucas Rangel, Juan de Toro y Hernando Domínguez Camargo. Los dos primeros cultivarían la ingeniosidad de los conceptos y el tercero se alistaría entre los gongoristas ${ }^{30}$.

La quinta: hay que reconocer que la vida comunitaria de los moradores de los pequeños colegios provincianos fue abnegada y heroica. Con solo tres jesuitas se debían cumplir todas las metas que definían el proyecto en cada ciudad. El colegio debía llevar a cabo la formación de hombres útiles y probos para la república cristiana con su norte siempre puesto en su lema "juntar virtud con letras", es decir, ciencia y conciencia. Y como complemento se instauraría la "Residencia" que debía encargarse del culto de la Iglesia, de las "Misiones circulares" y de fomentar la vida espiritual entre la feligresía que acudía al templo de los ignacianos.

\section{El marco del "humanismo" jesuítico}

Podría llamar a confusión el introducirnos en el selvático paisaje que se esconde tras el concepto actual de "humanismo" pues su abanico de concepciones es tan múltiples que puede abarcar desde el estudio de un período histórico hasta el análisis de un sistema cultural y de una ideología.

Sin embargo, como afirma Manuel Briceño Jáuregui, la gran novedad del Humanismo "fue la fundar por vez primera una cultura general, una guía del pensamiento y de la vida para llegar a la realización más alta de la carrera humana" ${ }^{\text {31 }}$. Y co-

\footnotetext{
29 Osorio Romero, 1980: 11.

30 Pacheco, 1959, I: 562-578.

31 Briceño Jauregui, II, 1991: 593.
} 
mo anotaría Uslar Pietri "Las humanidades no son otra cosa que una inmensa colección de la experiencia humana",

Y en verdad que la tradición greco-latina impuso un lenguaje científico y cultural universal que fue el latín y a él hay que recurrir para comprender la interpretación no sólo de las mentalidades de los hombres que integraron las comunidades humanas sino también las visiones de la ciencia que avalaba los cambios sociales.

Gabriel Méndez, al estudiar la personalidad de algunos jesuitas mexicanos del siglo XVIII, engloba a los seguidores de Ignacio de Loyola en la siguiente visión: "El humanista auténtico es el hombre que, mediante la asimilación de los más altos valores de la humanidad precristiana y su síntesis vital con los valores supremos del cristianismo, llega a realizar en sí un tipo superior de 'hombre' en el que la esencia humana logra florecimiento y plenitud" $"$.

Aquí nos circunscribimos a la forma cómo la Compañía de Jesús se insertó en esa corriente que tipifica el Renacimiento a través de los estudios humanísticos o las denominadas "litterae humaniores". Y para la mejor comprensión de este tema nos remitimos a los estudios realizados por François Charmot ${ }^{34}$ y a la síntesis que presenta Charles O'Neil ${ }^{35}$.

Con todo, una meditación sobre la paideia jesuítica exige otros contextos más amplios, pues la identidad de la naciente Orden religiosa se diseñó a través de tres grandes compromisos: un designio universal, una espiritualidad de compromiso activo con el mundo y el papel que asignó al trabajo de la inteligencia y a la adquisición del saber $^{36}$.

Desde los inicios de la Orden fundada por Ignacio de Loyola en 1540 la empresa misionera se evidenció como la genuina forja de la identidad jesuítica. Por una parte el celo religioso fue el motor de sus aventuras pues, al insertarse en el siglo de los grandes descubrimientos, les hizo sentirse herederos de esa dinámica de sueños, temores y entregas aprendidas en los Ejercicios Espirituales del fundador de la Orden; y así todos esos compromisos personales estimularon sus iniciativas, les impulsaron a luchar contra el conformismo y propiciaron en ellos la búsqueda de soluciones originales para problemas inéditos.

No se puede dudar que fueron audaces los retos que les impuso la era de los grandes descubrimientos. Podríamos citar, a modo de ejemplo, dos grandes experiencias: la república cristiana del Paraguay fue "una de las empresas más audaces de la historia de las sociedades, de las culturas y de las creencias" ${ }^{37}$ y también la confrontación científica con el mundo oriental, sobre todo con China, considerándola como "la expedición científica más ambiciosa de los tiempos modernos" ${ }^{\text {"38 }}$.

\footnotetext{
32 Uslar Pietri, 1970.

33 Méndez Plancarte, 1962: V.

34 Charmot, 1934.

35 O Neill, II, 2001: 1967-1971.

36 Giard, 2003: 17.

37 Lacouture, 1993: 548.

38 Ibíd.: 398.
} 
El embrujo de la "Misión"39 tuvo la capacidad moral de dotar a las primeras generaciones de energías y proyectos ilusorios encuadrados todos ellos en lo que Alfonso Alfaro denomina la cuaterna paradójica. En primer lugar, el compromiso adquirido en la interioridad de la experiencia religiosa. En segundo término, la obediencia que suponía una total disponibilidad de sus personas para la misión y la adquisición de un espíritu de cuerpo, todo lo cual implicaba una sintonía con los ideales de la Orden así como también con los mandatos de los superiores. Como tercer requisito se buscaba una preparación "élite" que facultaba al jesuita para hacer frente a situaciones sin precedentes y sin posibilidad de consulta y deliberación ya que en medio de tantas encrucijadas había que aportar soluciones a retos inesperados. Y finalmente la adaptación, que debía aprender las reglas del juego ajenas, penetrar lo más profundamente posible en el laberinto de imágenes y símbolos desconocidos y de esta forma tratar de precisar lo que divide para poder acentuar lo que une ${ }^{40}$.

También tenemos que subrayar que el compromiso con la educación y con los saberes se constituyó en una identidad adquirida en la naciente Compañía de Jesús. El deber de la inteligencia les condujo a una nueva "misión", a intervenir en el debate de las ideas sobre las que se está levantando un nuevo mundo. Inteligencia, imaginación y voluntad debían iluminar los caminos del compromiso con el hombre nuevo que surge del Renacimiento y con las sociedades que buscan una nueva forma de ser y de existir.

De esta suerte se gestó el lema ignaciano de juntar virtud con letras que los especialistas lo traducen en "pietas et eruditio", es decir, en esa difícil simbiosis que intenta armonizar "la vida con la ciencia", "la conducta con el saber" nadinas será el estudiante de teología Ignacio Julián quien sintetice los ideales de los ignacianos en la educación de la juventud en Colombia y Venezuela con su lema: "virtud, letras, números y política" 42 .

Este principio filosófico-educativo es clave fundamental para interpretar el aporte a la ciencia y a la ética en cada proyecto educativo y en cada región, pues, conjugados al unísono significaban una excelente simbiosis para perfilar la mejor expresión del hombre, uno e indisoluble.

El medio que utilizaron los seguidores de Ignacio de Loyola para alcanzar esos grandes ideales fue, al decir de Michel de Certaux, el "humanismo devoto" que en definitiva es el producto de una técnica: la retórica ${ }^{43}$. Según el jesuita francés la retórica distingue res (los significados: quae significantur) y verba (los significantes: quae significant) y todas las combinaciones posibles están reguladas por reglas (praecepta). En consecuencia, las res (que recolecta la eruditio) están destinadas a alimentar los mate-

\footnotetext{
39 Michael Sievernich comprueba que la voz "Misión" corresponde a la primera generación de jesuitas pues recoge el profundo simbolismo que constituyó para los ignacianos empeñados en dar respuestas a los retos globales que les propiciaba el mundo nuevo (Sievernich, 2005: 265-287). También en el mundo actual tiene vigencia el referente al espacio mítico que levanta la palabra "Misión" pues apunta a una acción mesiánica, a colonización ideológica o espiritual pues es un modo de exploración. Pero también pueden convertirse en modos de peregrinación, formas de prédica e instrumentos transitorios de colonización (Pinardi, 2006).

40 Alfaro, 2003: 16-17.

41 Lange Cruz, 2005: 56.

42 La primera edición impresa de la obra de Julián apareció en Del Rey Fajardo, 1979: 325-427.

43 Certau, 1974: 996-997.
} 
riales que componen los "temas", los "lugares" y las "ideas". Las verba permiten tratar los temas según los procedimientos que engendran los "estilos" y reaniman la "elocutio". Este sistema supone una verdad dada de fuera. De esta suerte la retórica la puebla únicamente por conocimientos objetivos (res) y las ilustra gracias al arte de hablar (artes dictaminis). Y de esta forma se transforma la retórica en la "ciencia del ornato". Su objetivo se centra en producir "efectos de estilo" que intentan producir "sentimientos" (amor, reverencia, etc.) y "acciones" (adhesión, prácticas religiosas...) en los destinatarios. En otras palabras es una técnica de la persuasión ${ }^{44}$.

Desde sus inicios la Compañía de Jesús independiza la retórica de la lógica y de la dialéctica pues no existe una verdadera teoría de la significación. Una doctrina de la verdad es sustituida por los teólogos jesuitas por un "moralismo". "La verdad a la que se adosa la retórica le es externa. Ella está cercada en la práctica y garantizada por las reglas ad pietatem et bonos mores, resorte y norma íntima de la vida religiosa o escolar. Significada por una organización de acciones y de la afectividad (opera et affectus), la verdad es custodiada allí dentro por un conjunto de prácticas. También las operaciones retóricas tienen por objetivo producir fuera, en los lectores o auditores, conductas y afectos (mores et pietas) análogas a aquellas que le sirven de apoyo. No se puede considerar la literatura devota de forma aislada; esta parte "retórica" implica otra mitad, interna aquella y ascética. Una estricta "disciplina" condiciona la "perfección de la elocuencia" 45 .

En consecuencia, Michel de Certaux habla de "retórica y espiritualidad" en los colegios de la Compañía de Jesús franceses y lo traduce al "humanismo devoto" producto de una técnica: la retórica y se remite para ello al tomo I de la Histoire littéraire de Henry Bremond ${ }^{46}$. Se trata de la técnica de la persuasión y para ello cita a Luis Richeome: "Es una cosa humanamente divina y divinamente humana saber manejar dignamente el espíritu y lengua de un tema..., alinear sus pensamientos con una sabiduría ordenada, revestirlos de un rico lenguaje..., plantar nuevas opiniones y nuevos deseos en corazones y arrancar los viejos, ablandar y someter las voluntades inflexibles..., y victoriosamente persuadir y disuadir aquello que se quiere" ${ }^{\text {"47 }}$.

Como es natural la formación jesuítica tenía un objetivo final: la "formación integral". Denominamos así al proceso instructivo y formativo, observado por los colegios de la Compañía de Jesús durante el período colonial, para obtener un resultado final que conjugara de forma armónica la capacitación intelectual y profesional, la práctica de las virtudes y el desenvolvimiento correcto en la sociedad ${ }^{48}$.

El humanismo integral contempla cinco elementos tradicionales que deben desarrollarse de forma armónica y jerarquizada. Ellos son: el físico, el social, el intelectual,

\footnotetext{
44 Certeau, 1974: 997.

45 Ibídem.

46 Bremond, I, 1916.

47 Richeome, 1628: 648.

48 Biblioteca Nacional de Colombia. Sección de Libros Raros y Curiosos. Mss. 17. Lo mejor de la vida, Religión, Doctrina y Sangre recogido en un noble joven colegial de el Real, Mayor y Seminario Colegio de San Bartholomé, propuesto en Ynstrucción Christiano-Politica para el uso de dicho Colegio a quien lo dedica un Estudiante Theologo de la Compañía de Jesús en su segundo año a suplicas de la misma juventud noble. El texto íntegro en Del rey Fajardo, 1991: 325-427.
} 
el estético y el espiritual. Como entre ellos debe existir interrelación, todos colaboran para conseguir el fin último: el hombre integral.

\section{La estructura organizativa}

La grandiosidad de los grandes colegios jesuíticos de Europa puede ofrecer una perspectiva muy distinta a la que presentan los colegios provincianos de América. Por ejemplo, el Colegio Imperial de Madrid ya en su fundación disponía de 6 cátedras de estudios menores y 17 mayores además de los prefectos, 2 directores espirituales, 12 pasantes y 1 corrector $^{49}$. Además hay que tener presente el influjo que ejercían estas instituciones sobre las sociedades en las que se encontraban y sus repercusiones en la pintura, la arquitectura, la música, el teatro y la danza ${ }^{50}$ así como su contribución a las ciencias $^{51}$ y letras.

Pero, la universalidad de la Compañía de Jesús pronto le obligó a enfrentarse a las diferencias de culturas, regiones y continentes. Estos retos los recogía la Formula acceptandorum collegiorum anno 1588 recognita $^{52}$ en la que se pormenorizaban las exigencias que definían un colegio jesuítico tanto en la integración de la comunidad, como en el curriculum, la dotación del edificio y de las clases y los ministerios que debían desarrollarse en torno a la Iglesia. Pero, esta Formula excluía expresamente a las Indias y a las regiones transalpinas. Suponemos que la exclusión contempla la letra de algunas disposiciones pero no el espíritu global del documento.

En las Provincias americanas hispanas de la Compañía de Jesús, sólo ciudades como México o Lima podían aspirar a disponer de hombres y medios para poder llevar adelante el genuino ideal de la formación ignaciana. En un segundo grado se colocarían Córdoba, Quito, Santa Fe y otras. Y en el resto del continente se interponían grandes espacios en los que pequeñas ciudades pugnaban por adquirir identidad a la vez que levantaban lentamente su estructura institucional como parte de la maquinaria administrativa de la monarquía hispana.

Esta era la realidad de la mayoría de las poblaciones donde fue fundando colegios la Compañía de Jesús en las Provincias surgidas en las tierras descubiertas por Colón ${ }^{53}$. Como es natural las exigencias y los planteamientos de estas ciudades provincianas eran en muchos aspectos distintos a los de las grandes urbes, aunque los ideales educativos fueran idénticos.

De esta manera se debe estudiar la inserción de los miembros de la Orden de Ignacio de Loyola en la ancha y extensa geografía americana como agentes de los pro-

49 Escalera, I, 2001: 844.

50 O`Malley, 2005: 3-16. O`Malley, et al., 1999 y 2002. Baldini, 2000.

51 Véase: Feingold, 2003. Hellyer, 2005. Romano, 1999.

52 ARSI. Institutum, 40, fol., 109-111v. Posteriormente, sin variaciones de fondo, se promulgó la Formula acceptandorum collegiorum iuxta V Generalis Congregationis, Decretum 87, a R. P. N. Claudio Aquaviva, Praeposito Generali, explicata.

53 La cronología de ingreso de la Orden de Loyola en la América hispana es tardía y doblado el siglo XVI: En 1566 llegan a la Florida, en 1567 al Perú, en 1572 a Méjico, en 1586 a Ecuador, en 1593 a Chile y posteriormente a la región del Plata, al Paraguay y al Nuevo Reino. 
legómenos de una historia intelectual en la que hay que dilucidar cómo y por qué han concurrido a la obra común de engendrar la modernidad ${ }^{54}$.

Pensamos que una de las intuiciones de los seguidores de Ignacio de Loyola en los nuevos mundos fue la de poder diseñar un modelo de "escuela" que funcionaba con cuatro jesuitas en ciudades que generalmente no alcanzaban los 1.000 habitantes. Así nació el "colegio indiano" que fue capaz de llevar adelante un revolucionario sistema educativo-formativo en las nacientes ciudades americanas para así lograr los fines fundamentales de la educación.

La estructura del "colegio indiano" descansaba generalmente sobre cuatro personas. El Rector, responsable local de la vida escolar por él presidida. El Profesor de Gramática que atendía permanentemente la marcha de las aulas. El Procurador del colegio que iría adquiriendo dimensiones desorbitadas por los capitales y riesgos que debía correr para generar los productos y posteriormente mercadearlos. Y el Prefecto de Iglesia, encargado del fomento de los ministerios encaminados a la práctica de las virtudes cristianas no sólo de los alumnos sino también de los feligreses que acudían al templo jesuítico.

Desde un punto de vista institucional y legal la "máquina religiosa" era responsabilidad del Prefecto de Iglesia; la "máquina educativa" reposaba sobre el Director de Estudios (auténtico administrador de la empresa académica); la "máquina económica" descansaba sobre el Procurador (verdadero gerente de la empresa); y todos gozaban de funciones claramente diseñadas y delimitadas ${ }^{55}$.

Mas, en definitiva, todas esas fuerzas dependían legalmente del Rector, genuino presidente de la corporación y por ende a él competían las decisiones finales -dentro del ámbito de su competencia limitada- en todos los campos de las administraciones.

Por su parte, la estructura del poder decisorio reposaba sobre tres niveles distintos: el local, representado por el Rector; el provincial (que abarcaba toda una extensa demarcación geográfica llamada Provincia) presidido por el Provincial; y el romano que, dentro de la concepción monárquica de la Compañía de Jesús, se centraba en el poder, prácticamente omnímodo, del Prepósito General.

Paralela a esta jerarquía de poder institucional encontramos a los Procuradores (de cada domicilio, de cada Provincia y el General), piezas vitales para entender cada uno de los entes económicos o la constelación de todos ellos. Su poder era gerencial y dependiente del respectivo nivel (Rector, Provincial, Prepósito General).

\footnotetext{
54 Giard: XV. Para un estudio de la misión e identidad de la Compañía de Jesús nos remitimos a: Sievernich y Switek, 1991.

55 Regulae, 1590: 176-189.
} 


\section{Cuadro 1}

\section{Plan de estudios según la concepción}

de Ignacio de Loyola

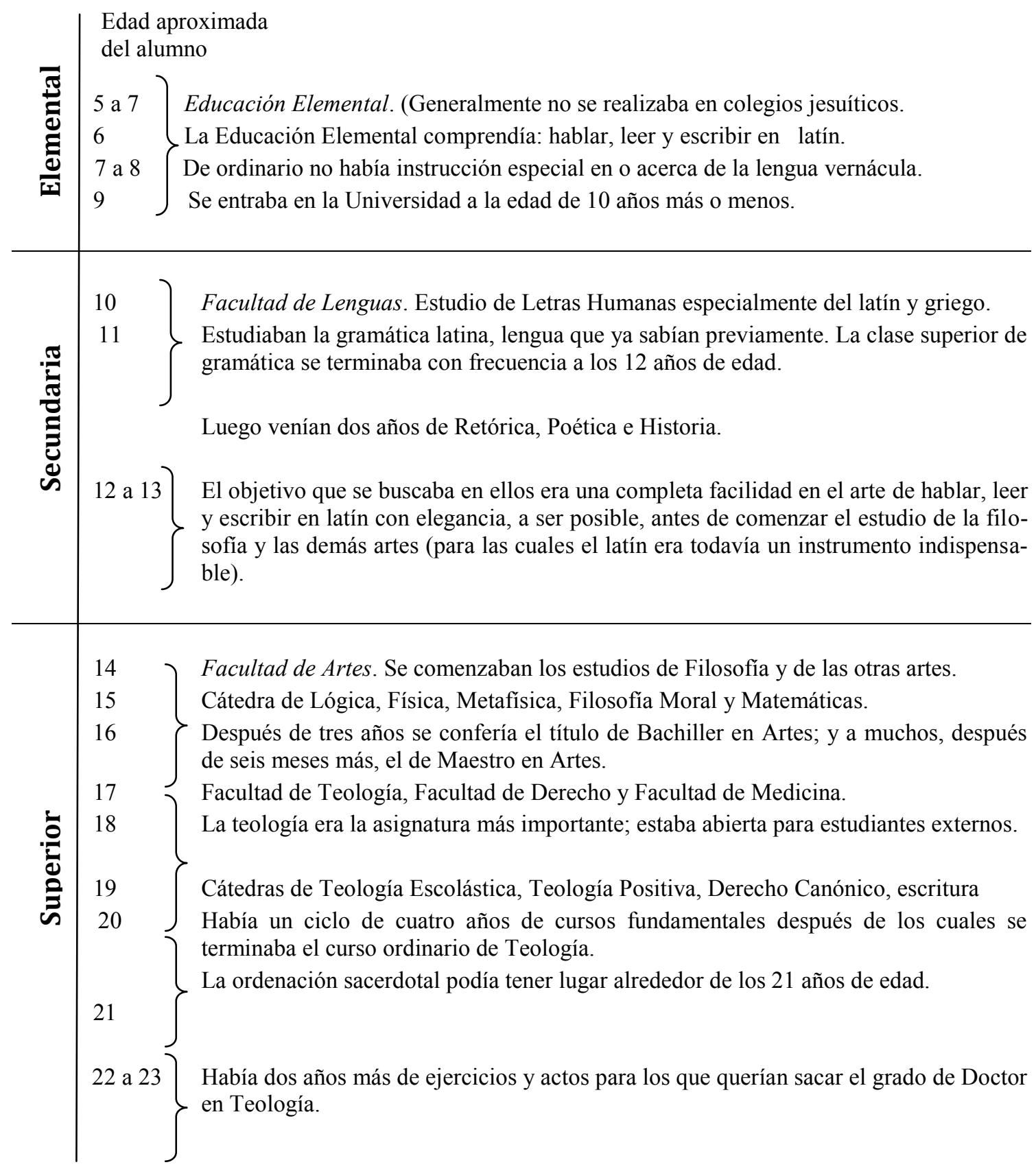

\section{EI Rector}

La cabeza visible de la obra total del colegio indiano era el Rector. Por ello en sus respectivas reglas se le recuerda que debía preceder a todos con el ejemplo ${ }^{56}$.

56 Regulae, 1590, Regla, 20. 
Mucha importancia atribuía la Compañía de Jesús de comienzos del siglo XVII a las costumbres ${ }^{57}$ tanto comunes al cuerpo universal de la Orden como a las específicas de cada provincia y casa. El esfuerzo unificador llevado a cabo por el P. Claudio Aquaviva y sus consiguientes consultas a todas las provincias esparcidas por el mundo representan la búsqueda de una identidad jesuítica que debía prevalecer sobre continentes, razas e ideologías. Ello explica el compromiso que asumía cada Rector frente al futuro de una orden religiosa nueva que se había extendido tan rápidamente por el universo conocido.

Pero como el cultivo de la vida espiritual de la comunidad jesuítica era el único medio válido para llevar adelante los ideales tanto religiosos como culturales, educativos y económicos del colegio, al Rector le correspondía mantener con ilusión y entrega la respuesta personal y comunitaria de cada uno de los integrantes de su jurisdicción ${ }^{58}$.

En la vida práctica era muy difícil que el Rector se moviera con igual competencia en las tres áreas de acción del colegio; lo lógico era que su gestión fuera más directa en el templo y en el colegio y más a distancia cuando se trataba de las haciendas.

Sobre el Rector recaía la responsabilidad inmediata y última de la buena o mala marcha del plantel educativo. Además, debía asumir las principales funciones del Prefecto de Estudios. Debía fomentar el entusiasmo del Profesor de Gramática ${ }^{59}$ para mantener vivos los programas educativos y evaluar cada mes con el docente el desarrollo del curso ${ }^{60}$. Asimismo debía asistir a los ejercicios literarios prescritos ${ }^{61}$ para garantizar su buen éxito. También tenía que presidir la entrega de los premios ${ }^{62}$, estímulo para inculcar la búsqueda de la excelencia. Y expresamente se le impone que funcione la Congregación Mariana ${ }^{63}$ de la que hablaremos más adelante.

El Prefecto de Estudios era el gestor directo e inmediato del funcionamiento académico del colegio a su cargo. Debía conocer a fondo la Ratio Studiorum ${ }^{64}$ a fin de poder exigir su cumplimiento. Pero en los colegios pequeños todas las funciones encomendadas al Prefecto las asumía el Rector.

Su gestión contemplaba: coordinación del profesorado; las admisiones y promoción de los alumnos; la supervisión de los exámenes y ejercicios literarios; y la disciplina.

En cuanto a los docentes, comenzaba por hacer guardar las Reglas correspondientes a los Profesores ${ }^{65}$, visitar las clases para tomar conciencia de su funcionamiento $^{66}$, verificar los calendarios ${ }^{67}$, controlar el pensum, que estaba referido en la Gramáti-

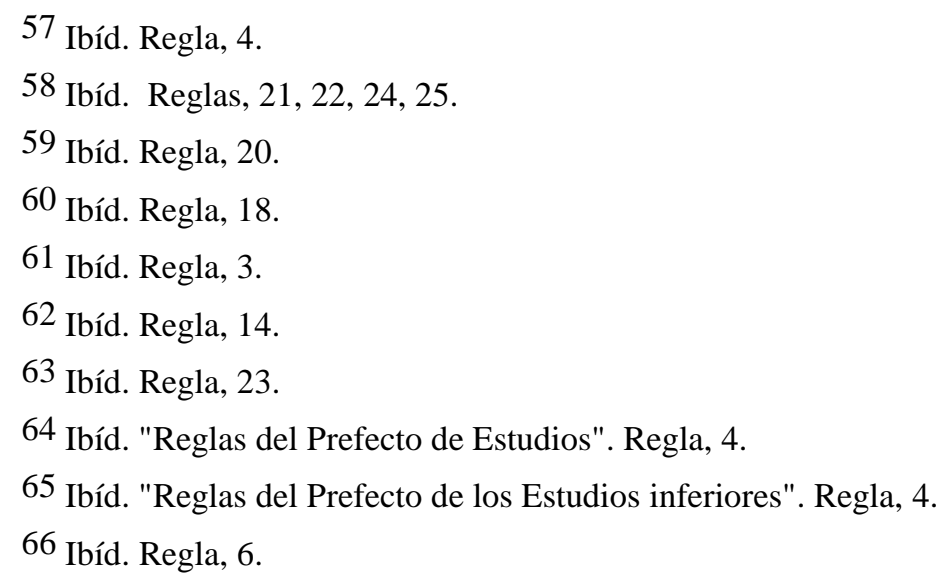


ca del P. Manuel Alvarez ${ }^{68}$ y en Retórica a la del P. Cipriano Soarez ${ }^{69}$; y velar por el prestigio y autoridad del profesorado ${ }^{70}$.

También debía supervisar el variado mundo de los ejercicios literarios: las declamaciones mensuales $^{71}$, las disputas de clases ${ }^{72}$, las Academias ${ }^{73}$, así como los premios públicos o privados ${ }^{74}$.

Finalmente debía cuidar de la disciplina del colegio, tanto dentro del aula como en los espacios que configuraban el recinto escolar ${ }^{75}$.

En definitiva se puede considerar que el Rector era el responsable directo de la buena marcha del colegio así como también el garante de la disciplina religiosa de todos sus moradores jesuitas. Pero, por otro lado, no se puede olvidar que la entidad a él adscrita formaba parte de un todo parcial como era la provincia del Nuevo Reino y en este sentido debía cumplir con normas que eran obligatorias para todos los planteles educativos.

Mas, para evitar cualquier desviacionismo Ignacio de Loyola había previsto la necesidad de que el Rector fuera asesorado por la denominada "Consulta domus" ${ }^{76}$ y vigilado por el Admonitor ${ }^{77}$.

Los consultores eran nombrados por el P. Provincial ${ }^{78}$ y su misión principal se dirigía a ayudar con su consejo al Rector para que el colegio obtuviera los mejores fru$\operatorname{tos}^{79}$. Su norte debía ser el bien común ${ }^{80}$. Si el caso lo ameritara podían remitir su opinión al superior mediato ${ }^{81}$. También debían escribir cíclicamente al Provincial y al General las relaciones que estatuía la "Formula scribendi" 82 .

El Admonitor lo elegía el Provincial ${ }^{83}$. Su misión consistía en advertirle al Rector de aquellas cosas que la mayor parte de los consultores juzgare oportuno hacerle ver o reflexionar y de aquellas otras relativas a la persona o al oficio dignas de ser tenidas

\footnotetext{
67 Ibíd. Regla, 7.

68 Ibíd. Regla, 8.

69 Ibíd. Regla, 13.

70 Ibíd. Regla, 4.

71 Ibíd. Regla, 32.

72 Ibíd. Regla, 33.

73 Ibíd. Regla, 34.

74 Ibíd. Reglas, 35 y 36.

75 Ibíd. Reglas, 43 y 44.

76 Regulae, 1590. "Regulae Rectoris". Regla, 14.

77 Ibíd. Regla, 15.

78 Ibíd. "Regulae Provincialis". Regla, 25.

79 Ibíd. "Regulae Consultorum". Regla, 1.

80 Ibíd. Regla, 2.

81 Ibíd. Regla, 7.

82 Ibíd. Regla, 10.

83 Ibíd. "Regulae Provincialis". Regla, 25.
} 
en cuenta ${ }^{84}$. Para mejor cumplir con su oficio debía poseer copia de todas las órdenes que los Provinciales dejaban al colegio "para que él pueda celar su observancia" ${ }^{85}$.

En la Provincia del Nuevo Reino estaba determinada la "Forma para haçer la entrega de un Collegio a su sucesor quando un Rector acaba su oficio" ${ }^{86}$. Se trata de un cuestionario pormenorizado acerca de la gestión rectoral durante el trienio de su mandato, cuyo texto debía ser firmado por la autoridad saliente y la entrante ${ }^{87}$.

\section{Cuadro 2}

\section{Organigrama de la estructura organizativa del Colegio indiano de Provincia}

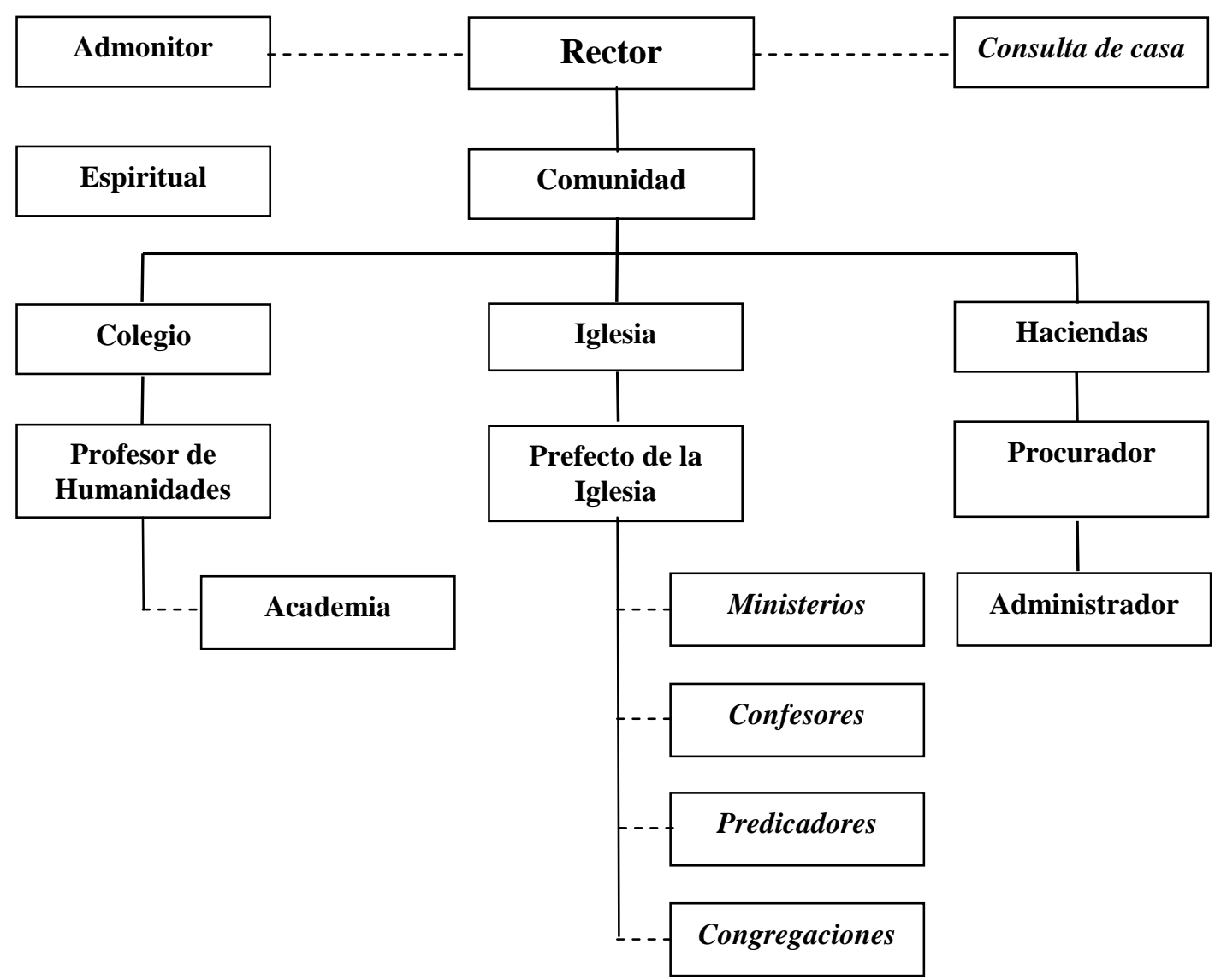

84 Ibíd. "Regulae Admonitoris". Regla, 3.

85 APT. Fondo Astráin, 18. Ordenes antiguas, que por orden de N. R. P. Lorenzo Ricci, ya no están en uso: y deven guardarse en el Archivo. Fol., 41.

86 Ibíd. Fol., 19v-20v.

87 Comienza con las entradas habidas desde la última visita del Provincial y si no hubiere habido visita desde el tiempo que entró en el oficio. Segundo: Descargos que da por el libro de gastos. Después "se saca el alcançe que se haçe diçiendo de que proçede". Deudas que debe el colegio: a quiénes y de qué. Deudas que deben al colegio: de quiénes y de qué. Rentas, censos, estado de las haciendas, etc. Debe dar cuenta de las alhajas de la Iglesia y Sacristía "por su libro", así como de la librería, despensa, cocina, refectorio. 


\section{El Profesor de Gramática}

El Profesor jesuita que se vinculaba al campo de la enseñanza de las humanidades era un profesional académico que había cursado tanto la Filosofía como las Letras en Universidades o Centros especializados, además de haberse capacitado en Seminarios prácticos en las técnicas de la pedagogía adoptadas por la Orden. Esta última exigencia se definió en 1565 en la Segunda Congregación General ${ }^{88}$ y se consagró definitivamente en la Ratio Studiorum de 1599:

"Para que los maestros de las clases inferiores no lleguen imperitos a enseñar, en los colegios de que suelen sacarse los maestros de letras humanas y de gramática, el Rector elija a alguno muy perito en enseñar con el que se reúnan al fin de los estudios tres veces por semana durante una hora los que están cercanos a ser maestros, para ser preparados al nuevo magisterio; y ello hágase alternativamente preleyendo, dictando, escribiendo, corrigiendo y desempeñando otros oficios del buen profesor" ${ }^{\prime \prime 9}$.

Pero a todas estas premisas hay que añadir otra, sin la cual se perdería la perspectiva real de la imagen del profesor jesuita: el magisterio surge, no sólo como una profesión, sino además como una misión específica y especial en la que no existe divorcio alguno entre su consagración al quehacer cotidiano en el colegio donde presta su servicio y sus ideales religiosos e intelectuales porque su espíritu corporativo había entendido que la semilla se sembraba individualmente pero el fruto cosechado hacía referencia a la comunidad.

La biografía del Profesor estaba enmarcada en el trabajo continuado: el estudio, la preparación de las clases, la dedicación a los alumnos y el cumplimiento de las demás normas de la Ratio Studiorum.

Su dedicación docente era exclusiva: Diariamente debía dictar 4 horas de clase: dos por la mañana y dos por la tarde ${ }^{90}$, de acuerdo con los programas prescritos y plasmados en las disposiciones educativas vigentes. También debía atender personalmente a la variada gama de los ejercicios previamente programados, los cuales podía cambiar "con tal de que se conserven los mismos enteramente y por los mismos espacios de tiempo en las reglas de cada maestro" ${ }^{91}$. El pensum anual debía cumplirse a cabalidad y era controlado por el Prefecto de Estudios ${ }^{92}$.

Su empeño fundamental debía cifrarse en seguir los pasos de cada uno de sus alumnos y buscar el mejor aprovechamiento ${ }^{93}$. Tenía que controlar diariamente los ejercicios de la memoria ${ }^{94}$, la entrega de composiciones las que debía corregir "con cada uno de los alumnos" ${ }^{95}$ y poner especial cuidado en preparar la prelección ${ }^{96}$. Cíclicamen-

\footnotetext{
88 Pachtler, 1968, I: 75.

89 Ratio Studiorum, "Reglas del Rector". Regla, 9.

90 Ibíd. "Reglas del Profesor de las clases inferiores", 14.

91 Ibíd., 15.

92 Ibíd., "Reglas del Prefecto de Estudios", 5.

93 Ibíd., "Reglas del Profesor de las clases inferiores", 50.

94 Ibíd., 19.

95 Ibíd., 20-21.

96 Ibíd., 27-30.
} 
te tenía que llevar a cabo los ejercicios extraordinarios, como concertaciones, etc. ${ }^{97}$. Y finalmente tenía que observar, a través de su Catálogo, la evolución intelectual de cada discípulo ${ }^{98}$.

El entusiasmo y la alegría debían ser sus constantes distintivos ${ }^{99}$ y junto a la dulzura y a la paciencia debía exigir la asiduidad de los jóvenes a clase ${ }^{100}$, el silencio y la modestia $^{101}$ y la guarda de las reglas ${ }^{102}$.

La disciplina la "conseguirá más fácilmente con la esperanza del honor y del premio y con el temor de la vergüenza, que con los golpes" ${ }^{103}$. Y en cuanto a los castigos impone la Ratio:

No sea precipitado al castigar, ni demasiado en inquirir: disimule más bien cuando lo pueda hacer sin daño de alguno; y no sólo no golpee él mismo a nadie (porque eso debe hacerlo el corrector), sino absténgase de ultrajar de hecho o de palabra; y no llame a nadie sino por su nombre o apellido; en vez de castigo será a veces útil añadir algo literario fuera de la tarea ordinaria ${ }^{104}$.

Y la última Regla del Profesor de las clases inferiores concluye con estos sabios consejos:

No desprecie a nadie, mire bien por los estudios tanto de los pobres como de los ricos y procure especialmente el adelanto de cada uno de sus escolares ${ }^{105}$.

\section{La misión del Profesor}

Pero la concepción del Profesor no se agota en las normas de la Ratio sino que supone una intensa vida ascética inspirada en los Ejercicios Espirituales de San Ignacio de Loyola. La tradición pedagógica de la Compañía de Jesús concebía al maestro como una célula inserta en el sistema educacional, y a la vez un átomo generador de los principios de la Paideia: autoridad, actividad y adaptación.

En la práctica, quien personificaba los ideales educativos expuestos más arriba era el profesor y a su responsabilidad inmediata se encomendaba la transmisión y difusión de los valores en ellos contenidos.

Así pues, no es de extrañar que hayan sido los escritores ascéticos de la Orden quienes más han insistido en las virtudes definitorias del maestro. La universalidad de esta doctrina la confirma el escritor neogranadino, el P. Pedro de Mercado (1620-1701), cuyo influjo en la formación de los jesuitas del Nuevo Reino en la segunda mitad del siglo XVII fue decisivo.

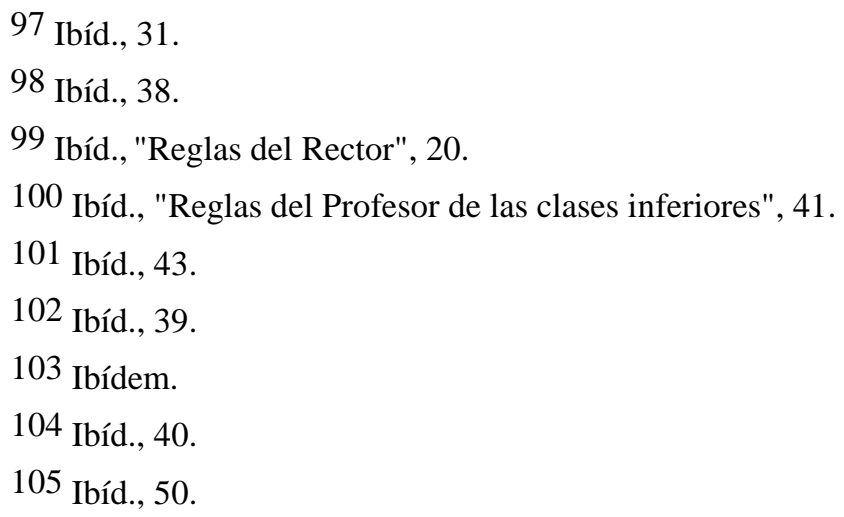




\section{Cuadro 3}

\section{Organigrama de formación del alumno en el Colegio indiano de Provincia}

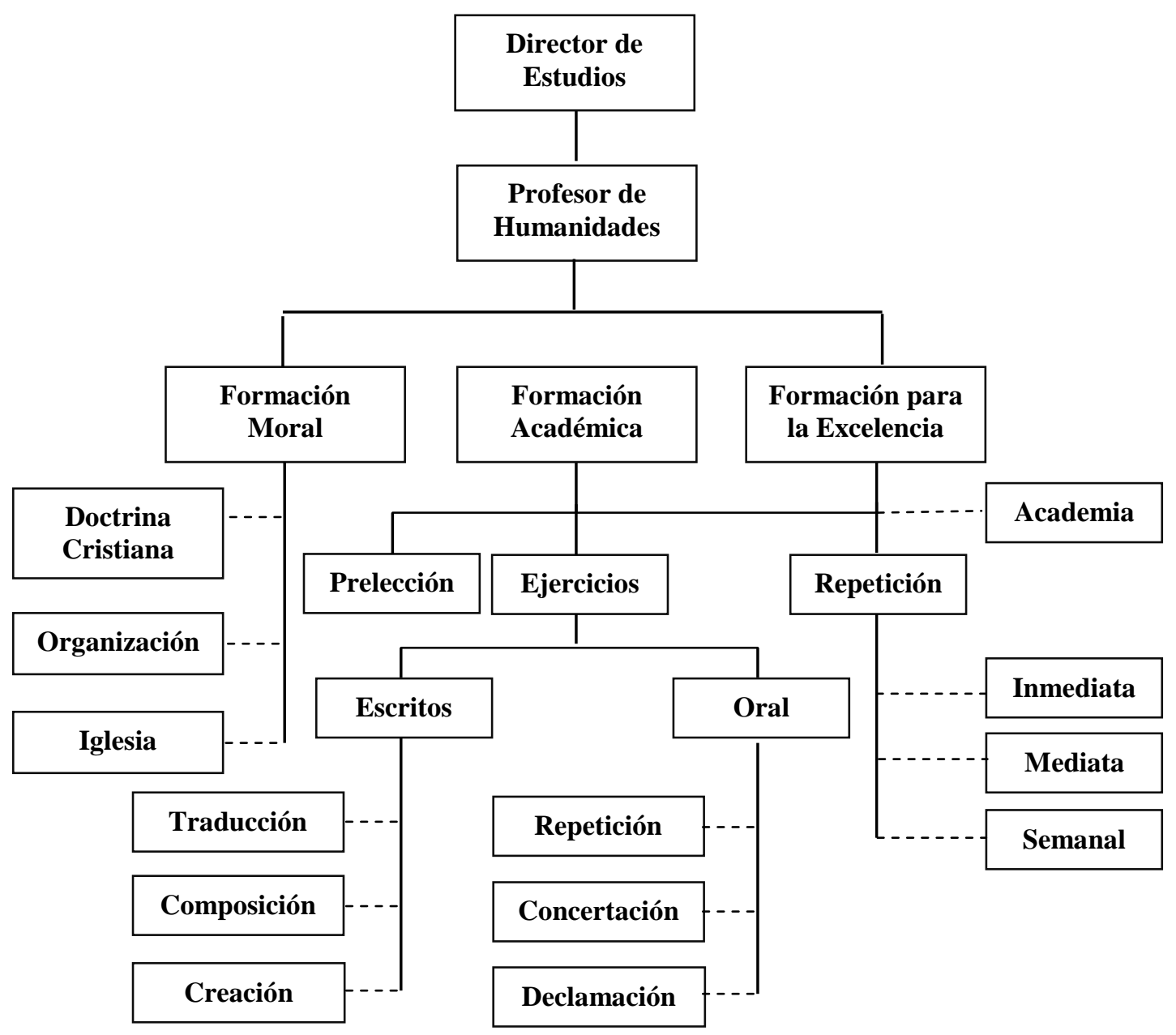

... pero viniendo a lo particular, puede el Maestro ejercitarse en las virtudes siguientes, entre las cuales vaya primero la caridad, como su Reina; ame a sus discípulos en Dios, por Dios y para Dios; y su amor, en las demostraciones exteriores, sea igual para con todos, no singular para con ninguno. Por tener oficio de alumbrarlos, desterrando las tinieblas de su ignorancia, debe ser como el sol, que no se singulariza con ninguno, sino que a todos igualmente alumbra y calienta. Pero si el Maestro es sol de otro hemisferio, y al uno alumbra con los rayos de su enseñanza, y al otro no; y si calienta a aquel con el calor de su caridad, y a los demás no, qué se ha de seguir sino la envidia, las quejas y la murmuración de los que no se ven tan favorecidos. Ponga gran solicitud en la enseñanza de sus discípulos... les leerá con claridad, los corregirá con blandura, las hará ejercicios con fervor, les preguntará con cuidado y les responderá con apacibili- 
dad, que a todo esto obliga el considerar que Dios le ha entregado a sus discípulos y que la Virgen le ha hecho Maestro de sus hijos adoptivos. Con qué solicitud se aplica uno al Magisterio de un hijo de un Rey, o de un gran Señor? Pues aún con mayor cuidado se debe aplicar el Maestro a la enseñanza de los pobres y de los ricos, porque son hijos adoptivos del Rey del Cielo y de la Reina de los Angeles. Tenga paciencia para sufrir las molestias que trae consigo la enseñanza de los que fueron rudos. No se exaspere cuando hay alguno de tardo ingenio, que Dios no le dio más. Haga su diligencia para desbastarlo con amor y tendrá con el rudo más mérito, que con la enseñanza de los más ingeniosos ... Oiga las quejas de los discípulos con sufrimiento y apacigüe con sagacidad sus rencillas. Que la paz hará que su aula sea un cielo, y la caridad que sean ángeles sus discípulos ${ }^{106}$.

Otro escritor ascético, el P. Antonio Le Gaudier (1572-1622), hacía las siguientes reflexiones sobre el tema del profesor:

Es menester que los adolescentes tengan mucha estima de sus maestros y hagan mucho caudal de su valer. Porque esta estima les apremia interiormente, sobre todo cuando se añade el amor, a cumplir en todo la voluntad de los que los dirigen. Razón por la que todo maestro debe esforzarse por conseguir este predicamento. Mas como ya hemos dicho a propósito del amor, se ha de tener cuidado en no complacerse en la popularidad. La reputación no es más que un medio; su valor moral depende del fin que se quiere alcanzar ${ }^{107}$.

En esta dirección dedica varios párrafos en los que insiste que el crédito es el fruto de las cualidades y virtudes, y se aumenta con la fama de sabiduría, pues los alumnos veneran a los profesores capaces de instruirles bien. En definitiva, se exige un hombre perfecto, de virtudes sólidas, prudente y discreto ${ }^{108}$.

Pero, también es necesario clarificar cómo se inserta la figura del Profesor en medio de los tres grandes principios que rigen la pedagogía ignaciana. La autoridad, concebida como un servicio a la institución educativa para garantizar tanto los ideales de la Ratio Studiorum, como los métodos que deben observarse para conseguir el fin propuesto y el perfecto orden que exige la complicada estructura de profesores, alumnos y programas. La adaptación, para hacer flexibles los métodos y procedimientos de tal manera que el objetivo final, el hombre, se pueda realizar en sus coordenadas espaciotemporales específicas. Y la actividad, conditio sine qua non, para que el hombre de la pedagogía ignaciana se constituya en el artífice de su propia vida como fruto de una opción nacida del criterio adquirido a lo largo de sus años de formación.

El alma de toda esta "fábrica"109 era la autoridad concebida verticalmente, la cual debe regular las relaciones estamentales: las externas, mediante la normativa de la Ratio, y las internas por la disciplina religiosa de una corporatividad que se rige por la obediencia.

\footnotetext{
106 Mercado, 1676: 238-239.

107 Le Gaudier, 1643: 119-120.

108 Ibidem.

109 Hemos adoptado el concepto de "fábrica", sacado del manuscrito del P. Ignacio Julián (Biblioteca Nacional de Colombia. Sección de Libros raros y curiosos. Ms. 17, fol., 17v): "... es mucha fábrica un hombre; y ejercita muchas acciones sobre todas las cuales tiene derecho la política, y en las del noble no perdona ninguna con tal autoridad".
} 
Este nexo entre autoridad y obediencia sólo es válido y eficiente cuando la obediencia es concebida como una virtud y no como mera disciplina. Así, el sentido de corporación en el que fue educado el jesuita, hacía que cada miembro fuera responsable de la consecución del objetivo final y total de la Compañía de Jesús mediante el cumplimiento fiel de su deber asignado, pues para él la obediencia, libremente aceptada, significaba un servicio, un estar siempre preparado para cualquier misión, para trabajar donde y en el puesto en que la institución necesitare la respuesta del súbdito.

Volviendo al tema principal, no es de extrañar que la Ratio Studiorum se pronuncie por la resultante de una cuádruple unidad: de dirección, de profesor, de método y de materia. En otras palabras: la Ratio exige un cuerpo de profesores formados en la misma escuela, imbuidos de los mismos principios, con unos objetivos comunes que deben ser adquiridos por los mismos medios.

Pero en relación con el alumno el Profesor debía adquirir otro tipo de autoridad:

La autoridad -escribirá el P. Juvencio en 1703- es cierta fuerza de mandar, de prohibir, de gobernar. Se la obtiene, o por derecho, o por habilidad. No basta de ordinario que el derecho la conceda si no vienen en su ayuda la habilidad y el talento $^{110}$.

Tres medios propone Juvencio para conseguir este fin: el aprecio, el amor y el temor. El aprecio sincero de los alumnos lo conseguirá el profesor por su cultura y su piedad. La cultura se demuestra dominando "profundamente la materia que debe enseñar" y "no diga nada que no lo haya limado y trabajado". Y la piedad se manifestará en las buenas obras ${ }^{111}$. conseguirá:

El segundo medio radica en procurar el amor de los alumnos, y el profesor lo

si lo ven deseoso de su provecho, moderado, dueño de si mismo, no suspicaz ni crédulo, sino tan amable y humano en privado como serio y grave en público, siempre ecuánime e igual con todos, no más amigo de unos, ni demasiado familiar; tardo en castigar ... Admita de buena gana las causas que pueda haber para perdonar o disminuir el castigo (...), que la culpa sea cierta y bien conocida, y si es posible, que el culpable la reconozca y confiese ${ }^{112}$.

El tercer medio para conseguir la autoridad lo constituye el temor filial. Por eso, el maestro debe mandar poco pero con rectitud "que exige lo mandado con constancia y prudencia". El laxismo y el rigorismo deben ser suplantados por la comprensión y la rectitud. La pedagogía ignaciana exige que se haga uso del poder con blandura y moderación ${ }^{113}$.

Uno de los mejores intérpretes de la primigenia mentalidad pedagógica de la Compañía de Jesús fue sin duda el P. Antonio Posevino (1533-1611). En su libro De cultura ingeniorum apela al testimonio de la historia y de la psicología para probar el principio de adaptación. Siendo la naturaleza humana la misma, los talentos son tan

110 Juvencio, 1703. Citaremos siempre por la versión castellana que publicamos en Del Rey Fajardo, 1979: 741.

111 Ibíd.: 741.

112 Ibíd.: 741-742.

113 Ibíd.: 743. Charmot, 1952: 121-123. 
diversos que consecuentemente hay que aceptar, a nivel cualitativo, selección y masa. De ahí la importancia que asigna a la necesidad de conocer la capacidad de cada alumno para poder adaptarse a él. De esta suerte escribirá:

Así como los elementos que engañan a la vista por la semejanza de su color blanco, como son la sal, azúcar, la harina, la cal, se distinguen sobre todo por el gusto, así las naturalezas que nos engañan con sus apariencias comunes no pueden ser conocidas sino por un examen detenido de su carácter íntimo ${ }^{114}$.

Si la autoridad debe oscilar entre la firmeza y la suavidad, la adaptación se moverá entre el rigorismo y el laxismo. Para su explicación hay que recurrir a los escritores ascéticos, como a los mejores intérpretes de la vida unitaria que debe surgir de la conjunción de la virtud y las letras. El P. Antonio Le Gaudier (1572-1622) puntualizaba sobre estos antagonismos:

Se cae en rigorismo:

$1^{\circ}$ cuando se dan lecciones, composiciones o tareas demasiado largas o difíciles; $2^{\circ}$ cuando las cosas fáciles se imponen a muchachos faltos de talento, de la memoria o de la ciencia necesarios; $3^{\circ}$ si se les habla en términos demasiado duros, desalentados o desalentadores, inspirados por el capricho; $4^{\circ}$ si se exige la lección o el tema para un tiempo fijo, sin tener cuenta con las legítimas excusas de la familia o el muchacho; $5^{\circ}$ si de buenas a primeras no se quieren oir las excusas presentadas con razón, sino que se las tiene por mentiras; $6^{\circ}$ si con la misma severidad se tratan las faltas graves y las ligeras; $7^{\circ}$ si nos mostramos suspicaces, incapaces de rectificar una impresión desfavorable, si somos avaros de elogios y pródigos en reprensiones; $8^{\circ}$ si mostramos desestima hacia un alumno y costumbre de interpretar torcidamente todo lo suyo; $9^{\circ}$ si no conocemos más que la rigidez de los reglamentos y olvidamos la flaqueza de la niñez; $10^{\circ}$ si las órdenes son oscuras, equívocas y dan pie a confusiones y a castigos imprevistos; $11^{\circ} \mathrm{si}$ negamos a carga cerrada los permisos solicitados con justa razón; $12^{\circ}$ si damos por ciertas las faltas dudosas, etc.

Se cae en el laxismo cuando:

no se hace caso más que de escándalos y faltas graves; el que para mostrarse suave no hace caso ni de la modestia, ni del comedimiento, ni del silencio; el que a fuerza de mirar la humana flaqueza, acaba por juzgar los males con excesiva indulgencia; el que reprende, pero, para evitar molestias o pequeñas protestas se abstiene de castigar; el que por amistad sensible o por complicidad, tolera que ciertos alumnos falten a la disciplina; el que so pretexto de bondad no se hace respetar; no menos que el tímido que no toma a pechos la observancia del reglamento; el maestro ligero que se distrae y se porta con los alumnos como un camarada $^{115}$.

El tercer principio se denomina actividad. Su concepción se basa en la continua y progresiva práctica del alumno en aquellos ejercicios que paulatinamente le ejerciten la memoria, le despierten la inteligencia y la formen la voluntad. En el fondo del siste-

114 Posevino, 1593, Cap. XIX. Citado por Charmot, 1952: 134.

115 Charmot, 1952: 121-122. 
ma subyace una verdadera teleología: el ejercicio programado para alcanzar la formación integral del hombre.

\section{EI Prefecto de Iglesia}

El templo significaba una actividad tan importante como la del colegio pues en el ideal ignaciano ambas entidades se debían complementar.

Así pues, el Prefecto de la Iglesia venía a ocupar un papel paralelo al que desempeñaba el Prefecto de Estudios para el colegio. En último término era el responsable no sólo de que el culto y los oficios religiosos adquirieran vitalidad e incluso esplendor sino que además debía responder por el orden y por la consecución de los altos fines ascéticos y espirituales que se proponía la Compañía de Jesús en cada domicilio.

Por ello, las Reglas correspondientes debían servir de norma y de guía ${ }^{116}$.

Las formas de comunicación para los jesuitas residentes en el colegio se ceñían a que los sábados se hacía público en el comedor el cronograma de la semana y se colocaba en la sacristía, por escrito, la información correspondiente ${ }^{117}$.

Con respecto a los sacerdotes debía verificar si observaban sus respectivas Reglas y si cuidaban de su porte exterior ${ }^{118}$; si disponían de las debidas licencias para confesar y si se acomodaban a las exigencias de los ritos de la liturgia romana ${ }^{119}$.

También debía celar porque se cumpliera lo estipulado por el fundador de la Orden acerca de la gratuidad de los ministerios y en consecuencia los sacerdotes no podían recibir limosnas ni por decir misa ni por oír confesiones ${ }^{120}$ y tampoco se permitían en la iglesia ni las alcancías ni ningún tipo de arca que permitiera depositar cualquier tipo de limosna ${ }^{121}$.

Aunque las reglas no bajan a detalles sobre los ministerios concretos, sin embargo precisa su obligación en procurar que no faltaran confesores en el templo ${ }^{122}$ así como la planificación de los sermones y de las lecciones sacras ${ }^{123}$.

Entre las obligaciones materiales permanentes sobresalen el conservar decentemente el Santísimo Sacramento ${ }^{124}$, renovar anualmente los santos Oleos así como custodiar las reliquias de los santos en un tabernáculo ad hoc ${ }^{125}$, y en fin procurar el ornato necesario para todo lo relativo al culto divino ${ }^{126}$.

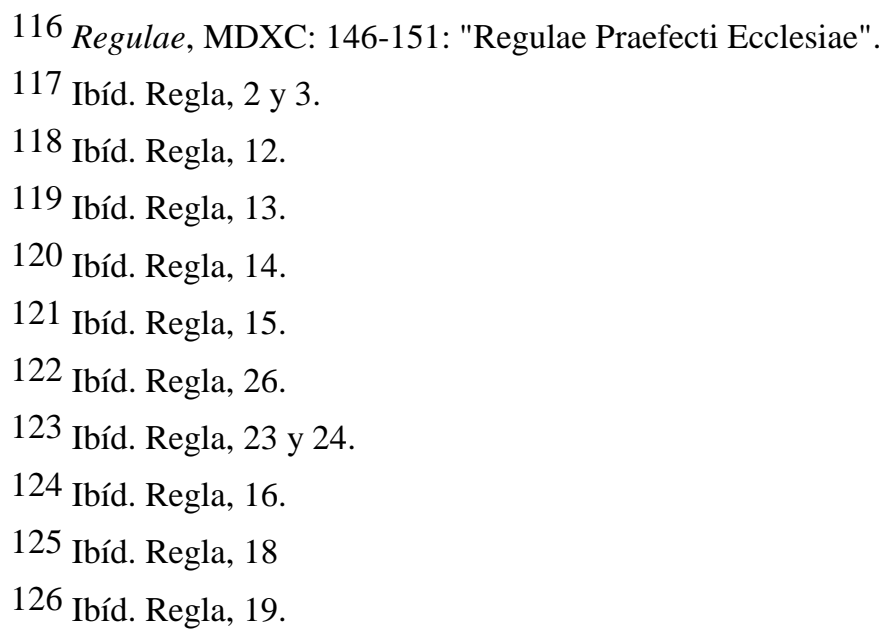




\section{La espiritualidad del colegio y el P. Espiritual}

El fervor espiritual del colegio tenía que traducirse en la buena marcha de todas las instituciones que en él funcionaban. De ahí la importancia que tenía la visita del P. Provincial cada trienio ya que significaba una auditoría espiritual y material tanto de cada uno de los integrantes del plantel así como también de todas las obras que funcionaban en la entidad-Colegio.

El alma de una comunidad jesuítica antigua era el P. Espiritual. Debía ser hombre maduro, de probada experiencia ascética, conocedor del Instituto de la Compañía de Jesús ${ }^{127}$, versado en la lectura de libros espirituales ${ }^{128}$ y experto en analizar los movimientos en que se debaten las almas ${ }^{129}$. Era el encargado de que el ideal ignaciano se concretase en cada uno de los miembros del colegio mediante el fiel cumplimiento de las reglas para conseguir la realización tanto espiritual como humana de cada uno de los jesuitas ${ }^{130}$.

Su acción pedagógico-espiritual era personal con cada sujeto y consistía en la dirección del mundo del espíritu y de la conciencia. Su objetivo se centraba en que cada dirigido espiritual alcanzara la familiaridad con Dios y el convencimiento de que el cumplimiento de sus obligaciones era el mejor servicio de Dios ${ }^{131}$. Para ello debía estimularlo, o corregirlo, o ayudarlo para que el proyecto de vida diseñado en los Ejercicios Espirituales adquiriera vida mediante los diversos modos de oración, el continuo examen, la práctica ininterrumpida de las virtudes y la lucha contra los afectos desordena$\operatorname{dos}^{132}$.

\section{El Procurador}

Podríamos definirlo no sólo como el asesor del Rector en asuntos financieros sino como el verdadero gerente de la "máquina económica".

Su actividad, de acuerdo con las Reglas del Procurador, se desglosaba en dos capítulos: la contabilidad y la administración.

Entre las sugerencias de política económico-administrativa, las Reglas son parcas pero precisas. Se parte del principio que, la responsabilidad, cuidado y aumento de los bienes materiales constituye la principal misión del Procurador ${ }^{133}$. Para ello se le encomienda la práctica de tres consejos: asesorarse en los asuntos delicados con los peritos más idóneos ${ }^{134}$; llevar con toda exactitud los libros de contaduría y archivo; e informar al Rector mensualmente del estado del balance y de la caja ${ }^{135}$.

\footnotetext{
127 Ibíd. "Regulae Praefecti rerum spiritualium". Regla, 1.

128 Ibíd. Regla, 5.

129 Ibíd. Regla, 6.

130 Ibíd.

131 Ibíd. Regla, 2.

132 Ibíd. Regla, 3 y 4.

133 Ibíd. "Reglas del Procurador". Regla, 1 y 11.

134 Ibíd. Regla, 17.

135 Ibíd. Regla, 4.
} 
En las compras se le recomienda que se lleven a cabo en el tiempo oportuno "a fin de que no se obligue a comprar las que no sean muy buenas o que no tengan precio equitativo"136 y una vez comprada la mercancía debía vigilar para que se conservase en buen estado ${ }^{137}$. Y dentro de este esquema administrativo debía tomar cuenta al comprador cada día de los gastos efectuados y obligarle a llevar un Diario ${ }^{138}$.

En relación al complicado mundo de los arrendamientos, contratos, contracción de deudas, o cualquier otro negocio de importancia, debía actuar con delegación del Rector $^{139}$ y de acuerdo con el informe de los peritos más idóneos ${ }^{140}$. Además, tenía la obligación de recordarle al Rector que, en los contratos de mayor importancia, debía remitir éste una copia autenticada a Roma ${ }^{141}$.

Finalmente, si había necesidad de recurrir a litigios judiciales se le advertía al Procurador que, antes de emprender el pleito, hiciera lo posible por llegar a un avenimiento o arreglo amistoso; y si esto fuera imposible, debía intentar siempre "una justa concordia" $^{142}$. En todo caso, los juicios debían ser llevados por procuradores exter$\operatorname{nos}^{143}$.

En lo que se refiere a la vida comunitaria los "Usos y costumbres la Provincia del Nuevo Reino" estipulaban la igualdad de todos los miembros de cada una de las comunidades jesuíticas expandidas por el Nuevo Reino. Así por ejemplo, en lo relativo a los viáticos de los que eran destinados a un colegio o residencia se fijaba tanto la dotación personal $^{144}$ como lo relativo a los viajes ${ }^{145}$.

Con todo, una serie de circunstancias muy singulares hicieron que la figura del Procurador adquiriese entre nosotros características muy singulares. Lo apartado de las haciendas, las ausencias para la búsqueda de mercados a fin de colocar los productos, el contacto con otros comerciantes, el volumen de ventas, etc. contribuyeron a que la realidad del Procurador adquiriera día a día mayor autonomía y por ende las relaciones Rector-Procurador tuvieran a veces que regirse por la vía impositiva de la obediencia.

136 Ibíd. Regla, 9.
137 Ibíd. Regla, 10.
138 Ibíd. Regla, 8.
139 Ibíd. Regla, 13.
140 Ibíd. Regla, 17.
141 Ibíd. Regla, 21.
142 Ibíd. Regla, 16.
143 Ibíd. Regla, 15.

144 APT. Fondo Astráin, 18. Ordenes antiguas, que por orden de N. R. P. Lorenzo Ricci, ya no están en uso: y deven guardarse en el Archivo. Fol., 23v-24: "El Colegio de donde sale, le dará el vestido interior y exterior y el manteo, sombrero, bonete y sobrerropa que tuviere dicho sujeto, de manera que pueda servirle todo deçentemente un año sino fuere necesario mejorarlo conforme al tiempo y lugar y la salud del que camina (...) y de la ropa blanca le dará tres camisas, tres pañuelos, tres escofias, tres pares de escarpines, dos pares de medias y dos pares de zapatos, jubón y calçones acomodados al tiempo y lugar a donde va".

145 Ibíd. Fol., 25v.: "14. Al que fuere de Santafe a Merida se le daran tres mulas fletadas y pagadas; veinte y cuatro panes; cuatro cajetas de conserva; quatro quesos, un quarto de carnero y treinta pesos en plata". 
Tres figuras jurídicas netamente diferenciadas en el derecho y en la historia de la Compañía de Jesús en Latinoamérica durante el período hispano intervienen en la administración de los bienes de cada domicilio: el Ministro, el Procurador y los Administradores de haciendas.

Pero un cargo tan delicado como es el del manejo de los bienes temporales es lógico que no fuera usual en la mayoría de los sacerdotes jesuitas cuya formación insistía fundamentalmente en los valores espirituales y en la formación humanística. Por eso puede llamar la atención que en diversas oportunidades fueran Hermanos coadjutores cualificados los que desempeñaran tal oficio.

En una acción tan universal como era la que desarrollaba la Compañía de Jesús en todo el mundo era lógico que existieran severos controles.

\section{Cuadro 4}

\section{Organigrama de estructura administrativa} en el Colegio indiano de Provincia

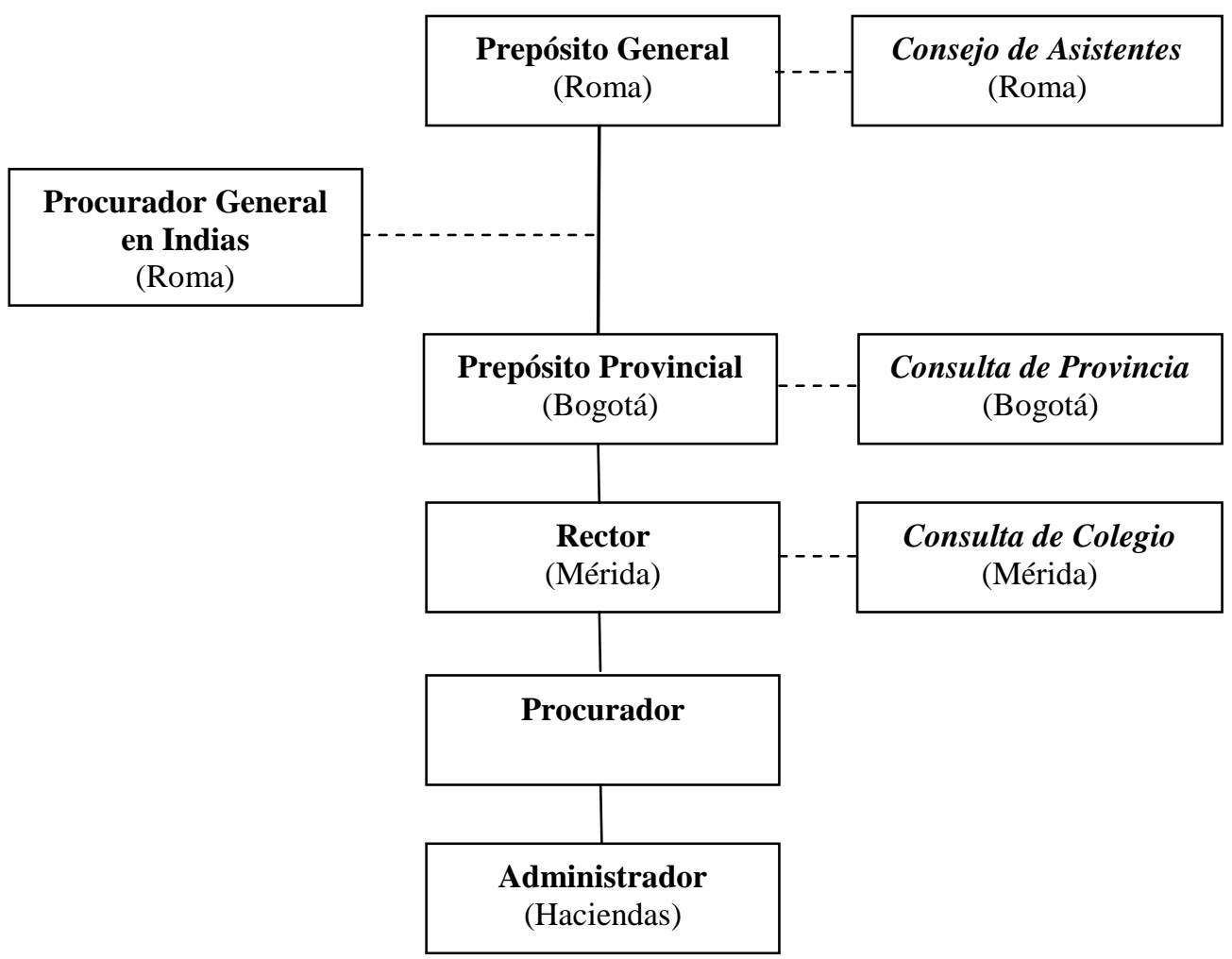

\section{La organización económica}

El estudio de la "máquina económica" que sustentó y movilizó la acción educativa, misional, social, económica, religiosa e intelectual de la Compañía de Jesús en el 
continente americano, se ha convertido en los últimos tiempos en un novedoso e interesante tema de investigación dentro de la historia social latinoamericana ${ }^{146}$.

La Compañía de Jesús partía del supuesto de que la "máquina económica" debía garantizar, fundamentalmente, un triple objetivo. En primer lugar, la gratuidad de la enseñanza que se impartiera en sus aulas; en segundo término, facilitar todos los medios para la construcción y mantenimiento del colegio e iglesia con las consiguientes dependencias anexas; finalmente, debía proporcionar subsistencia al equipo humano, siempre reducido en Indias, encargado de llevar a cabo la educación integral exigida por la Ratio Studiorum. Consecuentemente, es fácil comprender que los jesuitas excogitasen los medios financieros más eficaces a fin de garantizar la eficacia y la calidad en la realización de sus obras y en el rendimiento de sus hombres.

El punto de partida de toda institución docente jesuítica indiana consistía en la creación de una verdadera Fundación cuyo soporte financiero suponía una verdadera empresa, de cuyo incremento dependía en gran parte el florecimiento cultural del plantel, así como la dotación de todo el universo de sus dependencias auxiliares.

Sin embargo, este punctum a quo conlleva dos premisas de cuya comprensión depende en gran parte la recta interpretación del hecho económico llevado a cabo por los seguidores de Ignacio de Loyola en el Nuevo Mundo.

En primer lugar, la legislación de la Compañía de Jesús estipulaba muy sabiamente que cada colegio constituye un ente económicamente autónomo e independien$\mathrm{te}^{147}$. De esta suerte era corriente encontrar, dentro de una misma Provincia, obras sólidamente financiadas mientras que otras llegaban a padecer verdadera necesidad y penuria. Como contrapartida, los miembros de la Orden no podían ser adscritos de forma definitiva a ninguna casa en concreto y consiguientemente podían ser trasladados de domicilio libremente por el Provincial (autoridad máxima dentro de cada demarcación geográfica o Provincia).

En segundo término, la realidad económico-social de cada continente donde laboraba la Compañía de Jesús (Europa, Asia y América) era esencialmente distinta; de ahí la criteriología ignaciana de la adaptación a los tiempos, condiciones locales y personas imprimiera en el área económica la misma flexibilidad que en otros campos de acción. De esta suerte se explica que en tierras de Indias las Fundaciones no pudieran concebirse como fruto de grandes capitales (como sucedía en Europa), sino como un esfuerzo más, en un mundo en construcción, en el que la agricultura constituía prácticamente una de las pocas fuentes seguras de producción. Así fueron naciendo las grandes haciendas, al unísono con el esfuerzo de los hombres e instituciones que laboraban en la nueva América.

Así pues, antes de incoar un colegio se debía crear una Fundación, de la que surgiría después una empresa; una vez estructurada ésta, comenzaba a funcionar la máquina económica de cuyos frutos dependía la prosperidad académica y apostólica del plantel.

Pero conviene dejar fuera de toda duda que la "empresa" -a pesar de haber jugado un muchas ocasiones un papel importante en el quehacer jesuítico americano- fue

146 Morner, 1955. Colmenares, 1969. Samudio, 1985.

147 Constitutiones, 1943), nº 503, Apartado, 3. 
siempre un medio que sirvió para crear, sustentar, promover, incrementar y realizar los fines superiores inherentes a los ideales de la Compañía de Jesús. En otros términos, el criterio de empresa en lo económico hay que encuadrarlo dentro de la concepción jerarquizada de "apostolado", como un factor dependiente y subsidiario.

La documentación de que disponemos hasta el momento es bastante deficiente en lo referente a órdenes y criterios para manejar las haciendas en el Nuevo Reino. Sin embargo, sí se trasluce alguna información suelta que en el fondo se ajustaba a lo estatuido en las Reglas del Procurador.

En el provincialato del P. Francisco Antonio González (1720-1723) parece que las licencias que se tomaban los Administradores en la gerencia de las haciendas frente al Rector y Procurador de ellas llevó al Provincial a tomar medidas severas para corregir el abuso. Hace referencia el Provincial en su escrito a una orden del R. P. Juan Pablo Oliva, Prepósito General de la Compañía de Jesús, del 30 de agosto de 1673, de donde saca las siguientes conclusiones: "Lo $1^{\circ}$. No pueden dar ni disponer de cosa alguna sin licencia de sus superiores. Lo $2^{\circ}$ ni pueden hacer gastos extraordinarios, v. gr. edificios, rancherías, nuevos y costosos entables y cosas semejantes sin licencia de los superiores. Lo $3^{\circ}$ pueden y deben hacer aquellos ordinarios que ya se sabe son necesarios para llevar adelante las haciendas en sus cultivos, etc. y para la manutención de sus personas en la vida común de religiosos". Más adelante ordena y manda en precepto de santa obediencia a todos los Padres y Hermanos administradores de nuestras haciendas y a sus sustitutos (aunque lo sean por breve tiempo) que en los libros de recibo y gasto, que para esto deben tener en las haciendas, apunten y escriban no solamente todas las cantidades recibidas y gastadas, sino también de dónde procedieren los recibos (sean de frutos de arrendamientos, de envíos de los colegios o de cualquiera otra vía), que con ocasión de su administración o industria se hayan adquirido, y asimismo en qué se invirtieron las cantidades gastadas y que dos veces al año den cuenta a sus Superiores de dichos recibos y gastos, para que vistas y examinadas por ellos, les conste lo que se hace en las haciendas y puedan corregir lo que en esta parte juzgaren menos acertado ${ }^{148}$.

\section{Organización escolar}

\section{El pensum}

La Ratio Studiorum contempla para los cursos inferiores cinco clases o años: Infima, Media, Suprema, Humanidades y Retórica ${ }^{149}$. Los tres primeros años se dedicaban al aprendizaje de la Gramática. El cuarto se consagraba al estudio de las Humanidades, es decir, a preparar el camino para la elocuencia mediante el conocimiento íntimo de la lengua, el estudio de la teoría del estilo y la progresiva adquisición de la erudición ${ }^{150}$. En el quinto año se culminaba con la Retórica, la cual suponía la adquisición de la per-

148 ANB. Temporalidades, t. 18, fols., 812-813. Algunos ordenes y preceptos para los Padres y Hermanos administradores de nuestras haciendas intimados por el P. Francisco Antonio Gonzalez, Provincial de esta Provincia de la Compañia de Jesus del Nuevo Reyno. En este mismo legajo reposan interesantes informaciones sobre algunas haciendas de la Compañía de Jesús en el Nuevo Reino.

149 Ratio Studiorum.. "Reglas del Provincial", 12 \& 1.

150 Ibíd. "Reglas del Profesor de Humanidades", 1. 
fecta elocuencia mediante el estudio del arte retórico y poético y de una cultura integral $^{151}$.

En una ciudad provinciana era materialmente imposible poder aspirar a tal desideratum ya que no hubiera habido ni profesores suficientes, ni alumnos abundantes. Esta situación explica que debía ser bastante oneroso para el Profesor tener que atender simultáneamente los diversos estamentos de estudiantes.

Pero viniendo a las prescripciones curriculares de la Ratio debemos aclarar que la legislación escolar hacía referencia expresa a dos textos fundamentales: la Gramática del P. Manuel Alvarez ${ }^{152}$ y la Retórica del P. Mario Soarez ${ }^{153}$. Sin embargo, con el correr del siglo XVII observamos que también se recurre a los autores locales, regionales o nacionales: así los franceses adoptaron el Commentarii Grammaticae de Despauterio, los italianos querían mantener el libro de Coudret De primis latinae grammatices rudimentis libellus ${ }^{154}$ y en España Felipe III ordenó por real cédula del 8 de octubre de 1598 la imposición del denominado Arte Regio, una reedición de Nebrija a cargo del P. Juan de la Cerda cuyo título fue Aelii Antonii Nebrixensis de Institutione Grammaticae libri quinque, jussu Philippi III. Hispanarum Regis Catholici nunc denuo recogniti ${ }^{155}$. Y por citar otro ejemplo concreto, en el colegio de Zaragoza se introdujo para la lectura de los alumnos medianos, junto con el Nebrija, la Syntaxis de Torrella ${ }^{156}$. También en el Nuevo Reino debió imponerse a la larga el "Arte de Antonio" pues en 1689 lo imponía a los estudiantes de humanidades de la Universidad Javeriana el visitador, P. Diego Francisco Altamirano ${ }^{157}$.

Sin embargo, el programa de los estudios gramaticales de la Ratio recurre, como acabamos de mencionar, a la obra del jesuita portugués. En Infima se debe regir por el Libro I y una breve introducción de la sintaxis extractada del Libro II. En Media, el Libro II, desde la construcción de las ocho partes de la oración hasta la construcción figurada, amén de los apéndices más fáciles. Y en Suprema: del Libro II, de la construcción figurada hasta el fin y del Libro III, la métrica ${ }^{158}$.

Es interesante una opinión sobre el método utilizado por el P. Manuel Alvarez:

El método de Alvarez es muy cuidadoso y se diferencia claramente por la crítica del famoso Despauterio entonces en boga. Examina atentamente los ejemplos y las reglas de los antiguos y de los nuevos gramáticos, confronta sobre sus mismas obras los pasajes de los autores citados y obtiene de su lectura nuevas reglas y nuevos ejemplos. Supera en la elegancia, según dice Gaspar Sciopio, a todos los gramáticos antiguos y modernos. Este mérito ya le es reconocido por la pro-

\footnotetext{
151 Ibíd. "Reglas del Profesor de Retórica", 1.

152 Ibíd. "Reglas del Provincial", 23.

153 Ibíd. "Reglas del Profesor de Humanidades", 1.

154 Sommervogel, 1960, II, 1261-1263 donde recoge numerosas ediciones del libro.

155 Olmedo, 1949: 48.

156 Bartolomé Martínez, 1982: 48.

157 APT. Fondo Astráin, 18. Ordenes antiguas, que por orden de N. R. P. Lorenzo Ricci, ya no están en uso: y deven guardarse en el Archivo. Fol., 53: "7. La sylaba y poesia. Teniendo bien sabida y entendida con toda perfeccion la syntaxis y copia de los nombres y verbos con sus casos y la ortographia, todo como esta en el Arte de Nebrixa..."

158 Ratio Studiorum. "Reglas del Prefecto de Estudios Inferiores", 8 \& 2.
} 
visional Ratio Studiorum de 1586 que afirma: 'Si quid ... in syntaxi latinum, purum, tutum, elegans optari potest, id non ex aliis grammaticis, quia ea de re vel falso, vel impropie, vel barbare praeceperunt, sed ex Emmanuele [Manuel Alvarez] petendum videtur'. Es un método racional: expuestas brevemente las reglas, añade en cursiva, para los profesores, apéndices y comentarios llenos de observaciones y espigaciones históricas, filológicas, pedagógicas; denota estudio intenso y escrupuloso, lectura cuidadosa y minuciosa de los autores y gramáticos, erudición singular. En la sintaxis expone claramente las reglas más difíciles y con excepciones. Es una gradación de dificultades: las reglas comunes las acomoda a la capacidad de todos los estudiantes; en cambio los apéndices los reserva para los escolares más capaces y preparados y para los profesores. Toda la gramática comprende tres libros: etimología y morfología, sintaxis y prosodia. Sólo la morfología está intercalada con hexámentros de utilidad mnemotécnica, el resto en prosa. Más tarde Torsellino, en su reelaboración romana, le insertará versos también a la prosodia; versos que frecuentemente se le atribuyeron erróneamente al texto de Alvarez ${ }^{159}$.

Con respecto a las humanidades y retórica, si bien es verdad que se hace alusión al P. Mario Soares ${ }^{160}$ también se remite a la Retórica de Cicerón y a la Retórica y Poética de Aristóteles ${ }^{161}$.

Dentro del plan neogranadino de estudios debemos llamar la atención sobre el hecho que los jesuitas no patrocinaron de forma institucional el estudio del griego. Así se desprende de las mismas ordenaciones internas de la Provincia del Nuevo Reino relativas a la enseñanza. También confirma este fenómeno el jesuita italiano Felipe Salvador Gilij quien realizó sus estudios de Teología en Bogotá y en 1784 escribía desterrado en Roma- su opinión sobre los estudios superiores del virreinato neogranadino:

... yo hubiera deseado más para el cultivo de los buenos talentos de los hispanoamericanos: geometría, por ejemplo, historia natural, historia eclesiástica, griego y hebreo, filosofía menos sutil, teología más erudita ${ }^{162}$.

\section{Los textos}

Ciertamente resulta una tarea bastante comprometida escribir sobre la cultura clásica en el Nuevo Reino de Granada y Venezuela cuando todavía no contamos con obras fundamentales que recojan la historia del humanismo clásico llevada a cabo en estas tierras. Es de admirar los esfuerzos realizados en México sobre el tema: La Floresta de gramática, poética y retórica en Nueva España (1521-1767) de Ignacio Osorio Romero $^{163}$. Para Colombia hay que reseñar la obra El Latín en Colombia de José Ma-

\footnotetext{
159 Springetti, 1962: 283-304. Citado por: Osorio Romero, 1980: 134.

160 Ratio, 1590, "Reglas del Profesor de Humanidades", 1. "Reglas del Prefecto de los estudios inferiores", 13.

161 Ibíd. "Reglas del Profesor de Retórica", 1.

162 Gilij, 1954: 284.

163 Romero, 1980. Para una mejor información bibliográfica del tema puede verse, del mismo autor 1979.
}

141 José del Re Fajardo SJ. El colegio de San Francisco Javier de Mérida... 112-162. 
nuel Rivas Sacconi ${ }^{164}$ que viene a ser un primer intento para llevar adelante el proyecto para toda la época colonial.

Con todo, conforme se vayan conociendo y publicando las bibliotecas de los colegios coloniales se podrá ir reconstruyendo la infraestructura cultural de cada institución regida por los jesuitas. Para el presente estudio nos remitiremos a la biblioteca del colegio San Francisco Javier de Mérida (1628-1767) ${ }^{165}$ ya que, posiblemente, significaba el término medio de los colegios que la Compañía de Jesús mantenía en la circunscripción del Nuevo Reino y Venezuela.

Pero antes de entrar a este análisis creemos conveniente establecer dos observaciones. Una, hace referencia a la presencia de algunos libros no usuales en las grandes urbes americanas y ello, a nuestro parecer, se debe a la acción de algunos jesuitas centroeuropeos que enseñaron gramática en Mérida o rigieron los destinos del plantel educativo. Otra, que cada profesor portaba siempre los libros de su pertenencia y ello explicaría algunas ausencias notables de obras que per se debieran reposar en los anaqueles de la biblioteca. Formuladas estas salvedades pasamos a analizar el repositorio humanístico del colegio.

Nos llama poderosamente la atención que no aparezca en el inventario de la biblioteca del colegio San Francisco Javier la Gramática del P. Manuel Alvarez, expresamente prescrita por la Ratio Studiorum. Sin embargo, sí se reseñan dos ediciones de ella en el colegio de Caracas ${ }^{166}$ y otra en el de Maracaibo ${ }^{167}$. Su ausencia en 1767 no indica que no fuera conocida por los profesores del plantel merideño. Y en este contexto conviene señalar la presencia del belga Nicolaus Clenardus [Kleynaerts], muy conocido por sus gramáticas griega y hebrea ${ }^{168}$, en los anaqueles javerianos; con todo no hemos podido identificar del todo el libro que se reseña en Mérida: Conjugationes verborum, de pronomine, de articulis et de adnotationibus Renati in grammaticam Clenardi ${ }^{169}$. La Gramática griega de Clenard fue ampliamente utilizada en los colegios franceses regidos por la Compañía de Jesús e incluso fue libro de texto en bastantes planteles jesuíticos galos; su éxito debió ser grande pues durante el siglo XVII conoció diversas ediciones. La primera, de 1619, Nicolai Clenardi grammatica graeca ab uno e Patribus Societatis Jesu recognita estuvo a cargo del P. Etienne Moquot ${ }^{170}$.

Entre los autores clásicos esenciales para la enseñanza nos encontramos en primer lugar con Cicerón: sus Cartas $^{171}$, sus Orationes ${ }^{172}$ y De officio ad Marcum fi-

\footnotetext{
164 Bogotá, Publicaciones del Instituto Caro y Cuervo, nº. 3, 1949.

165 Aunque en el presente libro publicamos en los anexos la Biblioteca del colegio San Francisco Javier, sin embargo creemos oportuno hacer dos observaciones. Primera, en las referencias únicamente citamos el número arábigo que antecede a cada información bibliográfica de la siguiente manera: Mérida. Biblioteca, $n^{\circ}$. Segunda, reproducimos el texto publicado en: Del Rey Fajardo, 1991: 245-420.

166 Del Rey Fajardo, 1991, edición de Cervera de 1740 y nº. 1142, también de Cervera, pero sin año.

167 Ibíd.. Biblioteca, no 1022.

168 Institutiones, 1529.

169 Ibíd., Biblioteca, no 878.

170 Dainville, 1978: 283-284.

171 Del Rey Fajardo, 1991, Biblioteca, nº 190. Sin lugar de edición ni año.

172 Ibíd. Biblioteca, no 203. Venecia, 1714.
} 
lium $^{173}$. Como complemento para el mejor conocimiento ciceroriano también reposaba el libro de Melchor de la Cerda Aparatus latini sermonis per topographiam perque locos communes ac Ciceronis normam exactius ${ }^{174}$. Asimismo estuvo presente Juan Luis Vives a través de sus Declamationes Syllanae ${ }^{175}$. Y como es evidente no pudo faltar Esopo con sus Fábulas con otras añadidas ${ }^{176}$.

En cuanto a los poetas observamos que, aunque los griegos no debían pertenecer al pensum habitual del colegio, si se manejó uno de los libros del hijo de Julio César Scaligero, José Scaligero. Ejusdem epigramata quaedan tum graece tum latine cum quibusdam e graeco versis ${ }^{177}$.

Entre los latinos se encuentra la gran trilogía de los grandes maestros. De Ovidio: sus Obras $^{178}$ y la Metamorfosis ${ }^{179}$; también se cita un libro, sin autor, intitulado Anotaciones sobre Ovidio ${ }^{180}$. De Horacio reposaban sus Poemata omnia ${ }^{181}$ y de Virgilio, sus Obras $^{182}$.

También el inventario de 1767 hace referencia a un libro no identificado todavía por nosotros; nos referimos a Carmina de Vanino Lidon ${ }^{183}$.

Nos parece pobre el haber relativo al teatro clásico pues sólo se recensan dos autores: Terencio con su Andria ${ }^{184}$ y Séneca a través de su editor Francisco Raphenlegio. Decem tragediae quae Senecae tribuuntur. Amberes, $1615^{185}$.

Entre lo que podríamos denominar como preceptivas, amén de Gracián, hay que señalar la obra clásica de las Instituciones de Quintiliano ${ }^{186}$. Es significativa la presencia de varios volúmenes de Valerio Máximo, autor medieval que tuvo gran difusión en el renacimiento español y en la enseñanza jesuítica. Su obra Factorum ac dictorum memo-

173 Ibíd. Biblioteca, nº 237.

174 Ibíd., Biblioteca, nº 200. Edición de 1598.

175 Vives, 1535. Del Rey Fajardo, 1991. Biblioteca, $n^{\circ}$ 802. Muy posiblemente el libro merideño responda a Declamationes Syllanae quinque.

176 Ibíd., Biblioteca, nº 278. La edición es de Lion, 1709.

177 Ibíd., Biblioteca, n ${ }^{\circ}$ 752. Edición de 1621. En verdad no hemos podido identificar con exactitud el libro mencionado. Conocemos el Florilegium epigrammatum Martialis graece. París, 1607. Agathias de Imperio ... Justiniani Imperatoris ... Accesserunt ... Epigrammata graeca (latine reddita per J. Scaligerum, 1594.

178 Se citan dos ejemplares, el primero (Del Rey Fajardo. Biblioteca, ${ }^{\circ}$ 557) de Valladolid, 1626 y el segundo (Del Rey Fajardo. Biblioteca, ${ }^{\circ}$ 555) de Amberes, 1719.

179 Ibíd., Biblioteca, no 565 . Edición de Colonia de 1659.

180 Ibíd., Biblioteca, nº 28.

181 Ibíd., Biblioteca, $\mathrm{n}^{\circ}$ 616. La edición era de Amberes, sin año.

182 Ibíd., Biblioteca. Dos ejemplares de Venecia, 1707 (No 798, 824) y uno de Sevilla de 1705 (No 825).

183 Lidon, 1611. Del Rey Fajardo, 1991, Biblioteca, $\mathrm{n}^{\circ}$ 805. Tenemos noticias del libro de Guido Vannino, Carminum libri IIII denuo impressi... pero su nombre es Guido y no Lidon.

184 Ibíd., Biblioteca, n 38. Debemos aclarar que por mala lectura transcribimos "Andria Theranti", pero debe ser: Andria Terentii.

185 Ibíd., Biblioteca, no 639.

186 Ibíd., Biblioteca, nº 619. Edición de Lion de 1555. 
rabilium libri IX se utilizó en Mérida a través de sus ediciones de Amsterdam (1639) ${ }^{187}$ y Valladolid (1676) ${ }^{188}$. De igual modo formó parte del trajín diario tanto la Ecclesiasticae retoricae $^{189}$ de Fray Luis de Granada así como también un libro que no tuvo especial difusión en América: nos referimos a Copia sive ratio accentuum de Francisco Robles $^{190}$.

El célebre pedagogo jesuita, Juan Perpiñá, recomendaba varias obras para el dominio de la elocuencia ${ }^{191}$ y entre ellas se encontraba la Polyanthea ${ }^{192}$. En verdad, los planteles de la Compañía de Jesús en Europa se sirvieron de un texto de Dominicus Nanus Mirabellius intitulado: Polyanthea, hoc est, opus suavissimis floribus celebriorum sententiarum tam graecarum quam latinarum exornatum ${ }^{193}$. En el colegio San Francisco Javier se manejó el Josephus Langius (Langio, Josef). Polyanthea novissima dividida en veinte libros, obra esclarecida que se refiere a las suavísimas flores de las mas celebres sentencias así griegas como latinas ${ }^{194}$.

A los libros antes mencionados hay que añadir los más clásicos del XVII y XVIII dentro del ámbito docente de la Compañía de Jesús: el Cipriano Soarez. De arte retorica ${ }^{195}$ y el Novus candidatus Rethoricae ${ }^{196}$ del P. Francisco Pomey, obra que sustituyó en Francia durante la segunda mitad del siglo XVII a la del jesuita portugués ${ }^{197}$. Durante el siglo XVIII fue muy utilizado en España y en América el Palatii eloquentiae vestibulum sive Tractatus duo de methodo variandae orationis de Francisco Macho$\mathrm{ni}^{198}$. Para la enseñanza de la retórica también se sirvieron de un texto muy socorrido en Centroeuropa, el de Cornelio Valerius [Wouters], fallecido en 1572, Tabulae totius dialectices. (París 1548) ${ }^{199}$. Según J-B Herman el recién fundado colegio de Colonia, en Alemania, recibió dos tipos de influencia; una, proveniente del colegio romano y otra de Sturm y los Hermanos de la Vida común y dentro de este contexto penetra Cornelio Valerio en las fuentes de la pedagogía jesuítica ${ }^{200}$.

187 Ibíd., Biblioteca, no 793. El título que le asigna el copista merideño es: Dictorum factorumque et memorabilium.

188 Ibíd., Biblioteca, no 799 y 846.

189 Ibíd., Biblioteca, nº 343. Edición de Lisboa de 1576.

190 Berlangue, 1565. Del Rey Fajardo, 1991, Biblioteca, nº 647.

191 Luckas, 1974, II: 642. Para la clase tercera recomendaba: "las Observaciones de Nizolii, Thesaurus Ciceronianius [Carolus Estienne. Thesaurus Ciceronis. Parisiis, 1556], Sententiae Ciceronis, Valerius Maximus [M. Valerius. Factorum dictorumque memorabilium libri IX ad Tiberium Caesarem Augustum], Exempla Sabelici [Marcantonius Coccio, Sabelicus dictus. Exemplorum libri X] ..., Polyanthea, Summa virtutum et vitiorum [Quizá se refiera a: Flores poëtarum de virtutibus et vitiis ac donis Sancti Spiritus].

192 Ibídem.

193 Savona, 1503.

194 Del Rey Fajardo, 1991, Biblioteca, $\mathrm{n}^{\circ}$ 389. El título verdadero era: Florilegii magni, seu polyanteheae ... libri XX.

195 Ibíd., Biblioteca, nº 689. Edición de Olisipon, 1611.

196 Ibíd., Biblioteca, nº 581. Lion, 1682.

197 Dainville, 1978: 194.

198 Del Rey Fajardo, 1991. Biblioteca, ${ }^{\circ}$ 466. Madrid, sin año. El inventario le da el nombre de Antonio.

199 Ibíd., Biblioteca, no 880.

200 Herman, 1914: 105. 
Para la enseñanza de la poesía latina fue el P. Bartolomé Bravo (1554-1607) el autor más socorrido con su obra Thesaurus verborum ac Phrasium ad orationem ex hispana latinam efficiendam; sin embargo, en Mérida tuvo vigencia el Thesaurus verborum, obra de su discípulo, el P. Pedro de Salas (1584-1664) ${ }^{201}$.

Dos escritos de Quinto Curcio manejaron los profesores emeritenses: el de sus Obras, edición de Amsterdam de $1700^{202}$ y la Historia Alexandri Magni, publicada en Amberes en $1726^{203}$. De igual forma perteneció al curriculum merideño el estudio de Suetonio aunque la edición conocida ofrezca algunas dificultades para su recta interpretación. En efecto, la lectura del inventario, realizada por funcionarios que al parecer no sabían latín, confundieron a veces los nombres de las portadas o portadillas de los libros. "Roterio Casares. Suetoni Tranquili. Lion, 1551"204. El libro más conocido de Suetonius Tranquillus es C. Suetoni Tranquilli de vita duodecim Caesarum libri VIII. Muy posiblemente Roterio sea el editor o el impresor y el copista merideño acortó el título y transcribió Roterio Caesarum Suetoni Tranquilli.

Entre los textos de consulta del profesor el colegio San Francisco Javier mantuvo el aprecio del italiano Lorenzo della Valle, más conocido como Valla (1407-1457). Su libro más representativo fue Elegantiae latinae linguae y así reposaba en la biblioteca aunque el inventarista lo haya recensado en castellano ${ }^{205}$.

Otro humanista imprescindible para el conocimiento de los clásicos fue Justo Lipsio (1547-1606) quien se hizo presente por sus Epistolae selectae ${ }^{206}$ y Obras que antes estaban esparcidas en partes y aora reducidas a ciertas clases y en nuebo cuerpo en utilidad de los lectores ${ }^{207}$. De igual forma aparece entre los latinistas el historiador jesuita Juan Maffeius. Selectarum epistolarum ex India libri quatuor ${ }^{208}$.

Varios fueron los Diccionarios fundamentales que cumplieron con la labor de consulta en las aulas jesuíticas merideñas. Antonio de Nebrija publicó por vez primera el Dictionarium latino hispanicum el año 1492 en Salamanca. El éxito alcanzado por la obra llevó al autor a adjuntarle un suplemento en 1495 intitulado Interpretación de las palabras castellanas al latín. A ambas obras se les solía encuadernar juntas y se les conocía con el nombre genérico de Vocabulario de Antonio ${ }^{209}$. El colegio San Francisco Javier disponía del Diccionario, editado en Lyon, en $1655^{210}$.

201 Del Rey Fajardo, 1991, Biblioteca, nº 774. Para mayor información: Uriarte, II, 1904: 609.

202 Del Rey Fajardo, 1991. Biblioteca, $n^{\circ} 618$.

203 Ibíd., Biblioteca, no 615.

204 Ibíd., Biblioteca, no 640.

205 Ibíd., Biblioteca, $n^{\circ}$ 870. Existe otro libro ( $N^{\circ}$. 641) de Juan Renerio intitulado Laurentii Valla elegantiarum latinae linguae. Lyon, 1551.

206 Ibíd., Biblioteca, n 400. "Sus Cartas. Lion".

207 Ibíd., Biblioteca, n 380. Lyon, 1613.

208 Ibíd., Biblioteca, n 477. Véase: Sommervogel, 1960, V: 294. Selectarum epistolarum ex India libri quattuor Joanne Petro Maffeio interprete. Olysipone, 1571.

209 Osorio Romero, 1980: 54-55.

210 Del Rey Fajardo, 1991. Biblioteca, nº 509. 
También reposó en sus anaqueles el socorrido Dictionarium octo linguarum de Calepino $^{211}$ y el Dictionarium historicum, geographicum, poeticum ${ }^{212}$ de Carlos Stephano [Estienne]. Para el lector poco advertido es necesario prevenirle sobre la existencia de la familia Estienne, famosa en el Renacimiento por su conocimiento de los clásicos y por sus obras ${ }^{213}$.

Para la enseñanza de la matemática solo tenemos noticia de Juan de Sacrobosco (Holiwood de Sacro Bosco). Matemática ${ }^{214}$. No se debe confundir al autor inglés John of Holywood, fallecido en 1256 y autor de la Sphaera mundi, con el jesuita Cristóbal de Sacrobosco, distinguido teólogo irlandés que sufrió cárcel en Inglaterra y falleció más tarde en su ciudad natal de Dublín ${ }^{215}$. En todo caso, Sacrobosco era utilizado al final del siglo XVII como texto de la enseñanza matemática en los colegios jesuíticos alemanes $^{216}$.

Sería interesante precisar cuándo y cómo fue adquiriendo el castellano mayor importancia en el pensum del colegio San Francisco Javier. Un punto que merece especial atención es el posible influjo de Gracián en el mundo americano y concretamente en tierras de la Provincia del Nuevo Reino.

Ciertamente la estética graciana fue la estética del XVII. Y como anota Batllori la Agudeza y Arte de ingenio fue una de las pocas obras que Gracián sometió sin temor a la censura de su orden, la cual la aprobó con loa y encomio ${ }^{217}$, hecho que demuestra que la Compañía de Jesús no la consideró contraria a las tendencias clasicistas de la Ratio. En la biblioteca del colegio de Mérida encontramos dos ejemplares de la Agude$z a^{218}$ y en el de Caracas aparecen El Criticón, El Oráculo y El Héroe $e^{219}$.

En este orden de cosas pensamos que el influjo de Gracián fue definitivo en muchos campos de la Retórica hispana, aunque hay que reconocer con Batllori que el problema del paso de la Retórica de la Ratio a la retórica jesuítica del pleno barroco, es el mismo problema del tránsito de la retórica aristotélica a la retórica barroca (...). Los portillos de escape fueron los tópicos y figuras, el ingenio y la invención. Aristóteles los alaba y encomia, pero los recomienda con moderación (...). Lo mismo hace la Ratio

211 Ibíd., Biblioteca, no 176, y no 195 , editado en 1620.

212 Dictionarium historicum, geographicum, poeticum ... gentium, hominum, deorum, gentilium, regionum, locorum ... Génova, 1638 (Del Rey Fajardo, 1991. Biblioteca, no 715.

213 Enrique Estienne escribió el Lexicon Ciceronianum; Carlos, Thesaurus Ciceronis; Roberto, Dictionarium, seu linguae latinae thesaurus. París, 1531.

214 Del Rey Fajardo, 1991. Biblioteca, no 709.

215 Sommervovel, 1960, IV: 447.

216 La Congregación Provincial de Alemania, reunida en 1573, establecía como textos para el estudio de las Matemáticas los siguientes: "Sphera Joannis de Sacro Busto [Sacrobosco]; Computus ecclesiasticus, Geometria Appiani [Petrus Apianus (1495-1551). Cosmographia. Landshut, 1524]; Arithmetica Euclidis Elementa; Cosmographia Pomponii Melae".

217 Batllori, 1958: 105.

218 Del Rey Fajardo, 1990: 209: La primera corresponde a la edición de Huesca de 1649 y la segunda como parte de sus Obras en la edición de Madrid, sin año.

219 Ibíd.: 292.

146 José del Re Fajardo SJ. El colegio de San Francisco Javier de Mérida... 112-162. 
jesuítica. Bastó perder el sentido de la medida -y en esto radica la esencia del barrocopara desbocarse por el sendero del barroquismo ${ }^{220}$.

En este sentido resulta muy atinada la acotación de Ceferino Peralta que al integrarse la Ratio en el equilibrio de la Escuela Aragonesa "se situaría en una zona también integradora del barroquismo y clasicismo" 221 .

En todo caso nos parece muy interesante la hipótesis formulada por el investigador madrileño Bernabé Bartolomé, quien afirma:

Miguel Batllori cree que los síntomas de barroquización de la Ratio se asoman en la permisividad para utilizar las lenguas romances en la enseñanza del latín. Después de haber leído bastantes obras de certámenes y fiestas literarias de colegios jesuíticos del siglo XVII y XVIII, en gran parte en castellano, y después de observar la carga de elementos clásicos en los autores castellanos del siglo XVII -algunos discípulos de la Compañía- llegamos a aventurar la hipótesis de que en muchas aulas de gramática de estos religiosos la enseñanza del latín era un pretexto para mejor aprender la lengua castellana y desde aquí se podría entender mejor la falsedad de algunas acusaciones en torno a la metodología en la enseñanza del latín. La teoría emblemática de las empresas, los simbolismos y alegorías, algunos modelos de jeroglíficos y desarrollos de geometría lingüística que hemos contemplado en documentos relacionados con el Colegio Imperial de Madrid nos hacen rebasar la idea del barroco para llegar hasta los caligramas del movimiento surrealista. Este apartamiento de lo clásico provocó la reacción de la Congregación XIV de la Compañía imponiendo la vuelta al clasicismo con la Ratio Docendi de Jouvancy ${ }^{222}$.

El P. Pedro de Mercado nos ha conservado, en la biografía que dedica al tunjano P. Diego Solano (Profesor de Gramática en el colegio de Mérida hacia 1650), un testimonio que ilumina indirectamente la tesis que sostenemos:

Cumplió tan exactamente con la de maestro de letras humanas como quien era tan consumado en ellas. Era en estas tan eminente maestro como lo atestiguan algunos papeles que corrieron en la provincia suyos, ya de panegíricos varios en prosa, ya de pomposos versos heroicos latinos con agudas poesías en romance, con esta eminencia que no le debía la pomposidad de los versos más desvelo que el formar currente calamo las letras con que escribía su afluencia sin quejarse por la priesa más acendrada ni la más pausada retórica ${ }^{223}$.

Mas, el devenir del siglo XVIII conllevó cambios radicales y ellos se pueden detectar de forma más luminosa en la biblioteca del colegio caraqueño en la que se evidencia el influjo de las ideas renovadoras provenientes de la universidad jesuítica de Cervera y sus abundantes publicaciones ${ }^{224}$.

Las huellas del siglo XVI y XVII en la biblioteca merideña son inconfundibles. El siglo XVIII se hizo muy tímidamente presente quizá por las penurias económicas del

\author{
220 Batllori, 1958: 111. \\ 221 Peralta, 1984: 552. \\ 222 Bartolomé Martínez, 1982: 56. \\ 223 Mercado, II, 1957: 88. \\ 224 Véase la Biblioteca del colegio de Caracas. En Del Rey Fajardo, 1990: 259-345.
}


colegio. Por ello observamos una gran escasez de literatura española, hecho no acorde con el rápido desarrollo que iría adquiriendo en ese siglo la lengua de Castilla.

Una pregunta obligada para el historiador de las ideas pedagógicas en el Nuevo Reino sería la actitud jesuítica ante "el Barbadiño", Luis Antonio Verney, con su polémico libro Verdadero método para estudiar y ser útil a la república y a la Iglesia ${ }^{225}$.

En España se conoció de inmediato la edición portuguesa de 1751 (la traducción castellana data de 1760) y de seguidas provocó intensas polémicas. Entre los jesuitas escribieron tanto el P. Isla en su Fray Gerundio como el P. Antonio Codorniu ${ }^{226}$, profesor del colegio de Barcelona. Sin embargo, al conocerse en 1760 en la universidad de Cervera el libro del arcediano de Evora, el profesor de humanidades P. Gallisá aclaraba de la siguiente forma su posición:

que el método proyectado por Barbadiño es muy bueno, que así se hiciese en España desterrando de las escuelas gramáticas y retóricas inútiles y prolixas (...)

Yo en Lérida leí al Barbadiño y no encontré sino las mismas ideas que nos dan algunos extranjeros y nuestro Mayans sobre la enseñanza ${ }^{227}$.

Este testimonio del P. Gallisá nos lleva a concluir que el Barbadiño era conocido en su versión portuguesa en Cervera antes de 1760 y en consecuencia es presumible que el P. Ignacio Julián, quien acababa de ser maestro de gramática en dicha universidad ${ }^{228}$, trajera al Nuevo Reino a su llegada en $1760^{229}$ tan importante polémica. Pero será la investigación quien dilucide este interesante asunto.

\section{Ingreso y promoción del alumno}

Para ingresar en cualquier colegio jesuítico se requería de la presentación de un examen a fin de poder colocar al alumno en la clase oportuna ${ }^{230}$. Al candidato se le debía interrogar qué estudios había realizado y dónde. La prueba consistía en la redacción de un tema y, de acuerdo con los cursos aducidos, se proponían algunas breves frases ya para ser traducidas al latín, o si el alumno estaba más adelantado para interpretar a un autor $^{231}$.

La admisión se reservaba a los que se conociera "ser instruidos, de buenas costumbres e índole"232. Debía llevarse el Libro de Admitidos en el que debía constar:

225 El título completo es: Verdadero método para ser útil a la República y a la Iglesia, proporcionado al estilo y necesidad de Portugal. Madrid, traducido al castellano por D. José Maymó y Ribes, 1760, 4 vols. La edición príncipe se editó en Lisboa en 1751.

226 Codorniu, 1764.

227 Casanovas, 1932: 31.

228 AHN. Jesuitas, 827/2. Filiacion de los Regulares de la Compañia del nombre de Jesus pertenecientes a la Provincia de Santa Fee de Bogota venidos en diferentes navios. № .178 : "... entró en la Compañía habiendo estudiado Filosofía, Leyes y Cánones el setecientos cincuenta y cinco en la Provincia de Aragón. Tuvo su noviciado en Torrente y Tarragona. Maestro de Gramática en la Universidad de Cervera".

229 AGI. Contratación, 5549. Expedición de 1760, fol., 14v.

230 Ratio Studiorum, 1590. "Reglas de los oyentes externos de la Compañía". Regla, 2.

231 Ibíd. "Reglas del Prefecto de los Estudios inferiores". Regla, 10.

232 Ibíd. Regla, 11. 
Nombre, apellidos, lugar de origen, edad, nombre de los padres o representantes y la fecha exacta de su admisión ${ }^{233}$. Expresamente se estatuye que "a nadie se excluya por ser innoble o pobre" ${ }^{234}$.

Desde el inicio de su vida escolar se les debía indicar a los jóvenes que todo el esfuerzo pedagógico se centraba en el convencimiento de que el resultado final debía ser uno y único; por ende, debían conducirse en todas sus acciones de tal manera "que todos entiendan de ellos que están dedicados no menos al estudio de las virtudes y de la integridad de vida que al de las letras" ${ }^{235}$. Para ello, en el momento de la admisión, se le debían mostrar las Reglas ${ }^{236}$ y además debían estar expuestas permanentemente en cada clase y una vez al mes debían ser leídas las específicas a cada estamento ${ }^{237}$.

La promoción de un curso a otro se llevaba a cabo únicamente al inicio de cada período escolar; sin embargo, aquellos alumnos que fueran sobresalientes de acuerdo con el estudio de sus notas y la opinión de los Profesores podían ser ascendidos a un curso superior, en cualquier época del año, siempre y cuando aprobaran el respectivo examen $^{238}$.

Los exámenes debían ser escritos ${ }^{239}$, presididos por el Prefecto ${ }^{240}$ y ante un Jurado compuesto por tres Profesores ${ }^{241}$. El Jurado debía revisar previamente, en el Libro de Notas, las calificaciones de cada uno de los examinandos para poderse formar un juicio objetivo $^{242}$. La nota definitiva debía contemplar: la composición, la nota del maestro y el interrogatorio ${ }^{243}$.

\section{El calendario escolar}

En los colegios del Nuevo Reino el calendario escolar lo iniciaban los "Estudios Menores" el día 9 de septiembre y lo concluían el 30 de julio, víspera de la solemnidad de San Ignacio de Loyola, Fundador de la Compañía de Jesús ${ }^{244}$. A lo largo del año escolar la semana se interrumpía el jueves que venía a ser el día de asueto ${ }^{245}$. Tampoco eran muy abundantes las vacaciones interanuales: se leía hasta la víspera de Navidad al mediodía y retornaban al aula el día 29 hasta el 31, cuya tarde era de vacación. En Carnavales el asueto se extendía desde el domingo hasta el miércoles de ceniza por la ma-

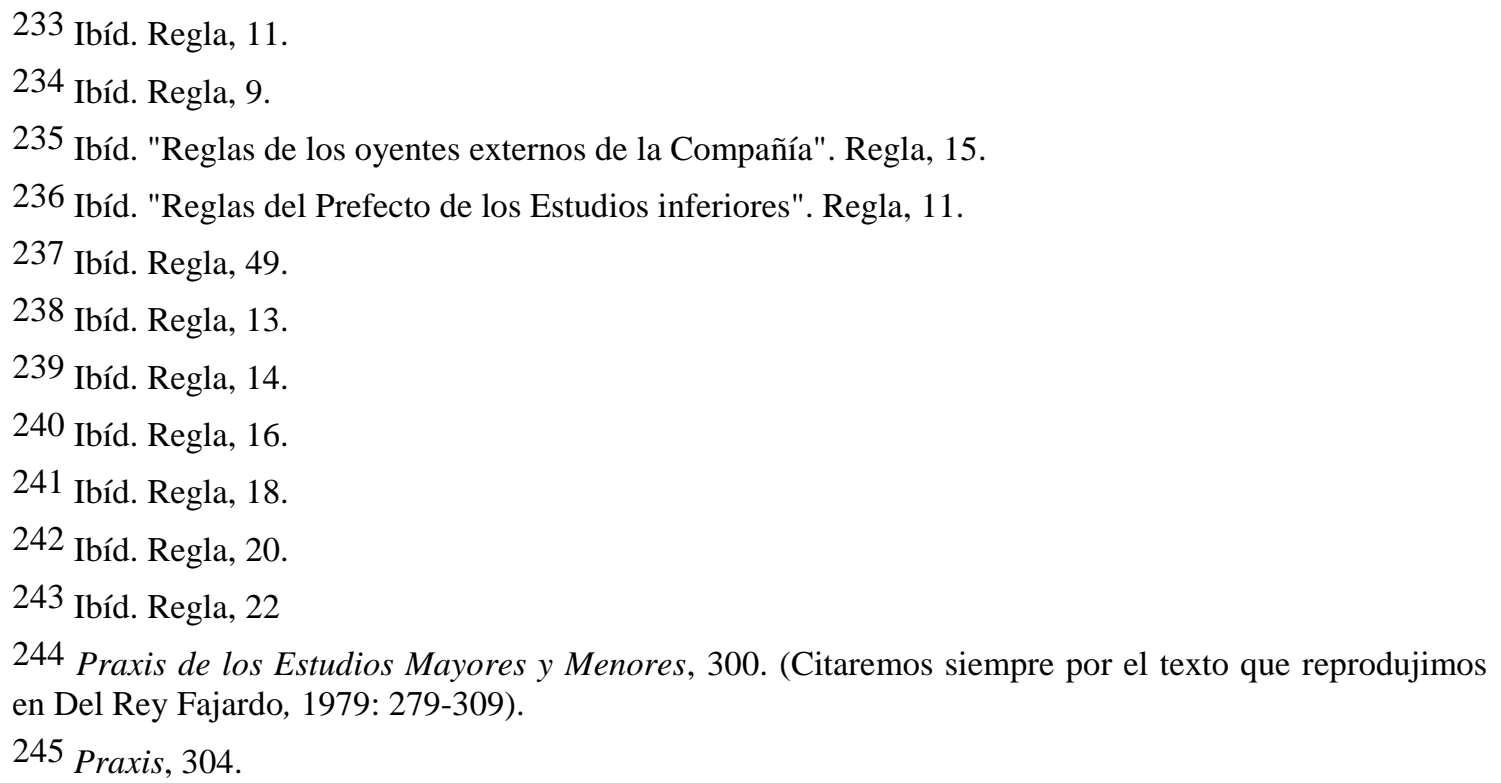


ñana. En Semana Santa, desde el miércoles hasta el tercer día de Resurrección. En Pentecostés desde su vigilia hasta el tercer día posterior a esa festividad. El día de Corpus Christi y su víspera por la tarde y la mañana de la conmemoración de los Difuntos. Ignoramos si se haría extensible a los demás colegios la costumbre quiteña que fijaba que los días "que hay toros en la plaza principal de la ciudad, no hay lección por la tarde" ${ }^{246}$. Los sábados por la tarde dedicaban la última hora de clase a la formación espiritual ${ }^{247}$.

El horario de las clases era eminentemente solar. Las puertas de los colegios neogranadinos y venezolanos se abrían para los jóvenes a las 7 de la mañana y la jornada escolar abarcaba mañana y tarde. La primera clase se iniciaba a las siete y media y la segunda a las diez y cada una tenía una duración de una hora. Ambas se interrumpían con un recreo de treinta minutos. Por la tarde también se dictaban dos horas de clase: a las dos y treinta y a las cuatro interrumpidas por media hora de descanso ${ }^{248}$.

Entre otras, hay dos normas llaman hoy la atención: que todos debían tener asientos $_{\text {fijos }}{ }^{249}$ y la importancia que se le asignaba al estudio privado ${ }^{250}$. También la planificación educativa imponía la redacción del catálogo de los libros que deberían utilizarse a lo largo del año ${ }^{251}$ a fin de dar tiempo a los libreros públicos para su consecución $^{252}$.

\section{Los actos públicos}

Los actos públicos eran parte esencial en la formación humanística de la Compañía de Jesús pues en ellos no sólo se evidenciaba la realidad de la competencia sino que además la incentivaba ya que de otra manera el éxito pasaba a otras manos.

Para ello se prescribía al maestro que "puliera" los escritos de los alumnos y sistemáticamente tenía que prepararlos para actuar en público ${ }^{253}$. También era deber del profesor la ejercitación tanto en declamaciones privadas que debían realizarse desde la tribuna la última media hora de $\operatorname{los}$ sábados $^{254}$ y las públicas que se tenían cada mes "en el aula o en el templo" 255 . En ese contexto el maestro debía asimismo proponer en clase representaciones breves para que los alumnos las declamasen, estudiados los papeles, en vez del argumento ${ }^{256}$.

Lógicamente, el haber aprendido de memoria textos clásicos de gran valor literario y el haber tratado de imitarlos y aun de superarlos en los ejercicios diarios de clase,

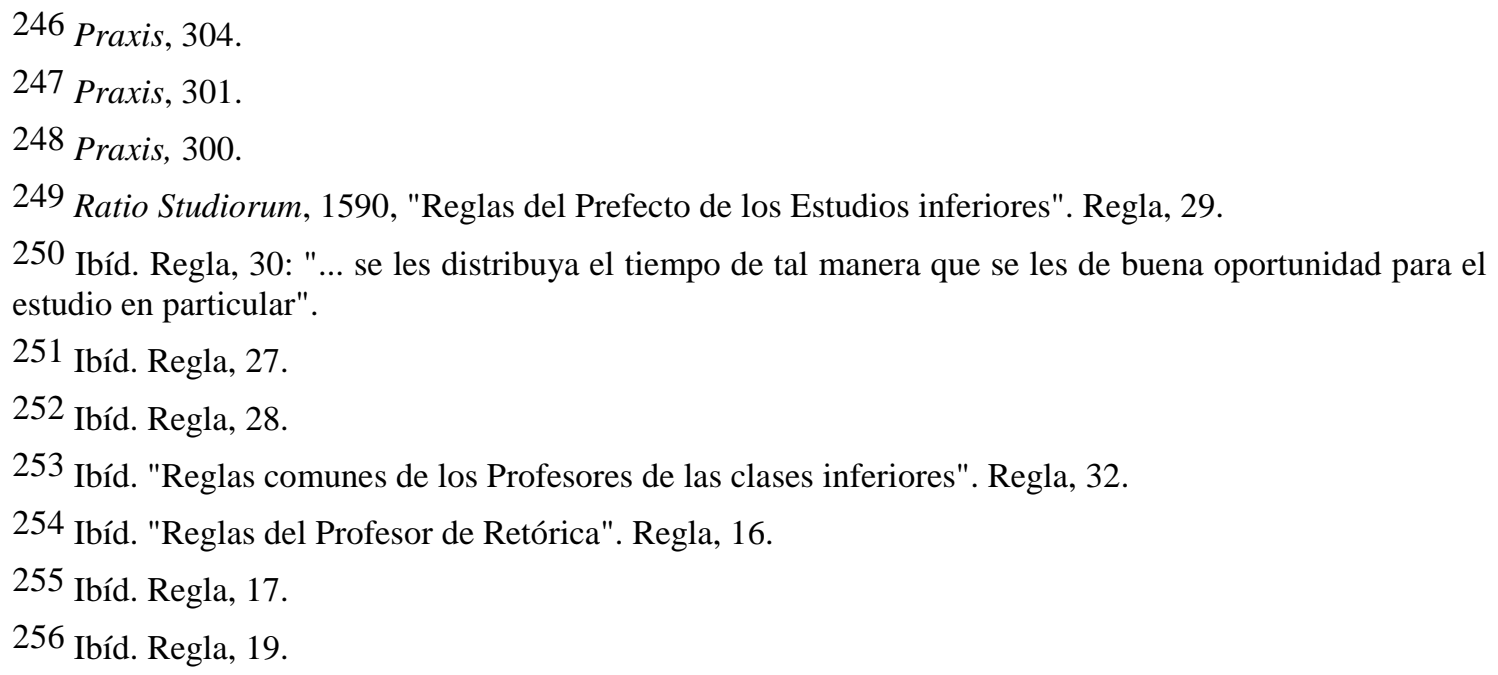


amén de haberse compenetrado con el ritmo de los argumentos y el estilo del discurso constituía una base sólida y segura para que el estudiante adquiriera facilidad para la oratoria y la retórica.

Pero si la imitación se constituía en el primer tramo de la capacitación humanística de los gramáticos, al avanzar en los estudios se veían a diario forzados a apelar a la creatividad tomando como pretexto cualquier ocasión propicia. Para ello, no sólo debían componer poesía, sino:

... según la costumbre de la región, [redacten] algo en prosa más breve, como son las inscripciones, escudos, templos, sepulcros, jardines, estatuas; como descripciones de una ciudad, puerto, ejército; como las narraciones de alguna hazaña de alguno de los dioses; como finalmente paradojas, añadiendo a veces, pero no sin permiso del Rector, pinturas que respondan al emblema o argumento propuesto $^{257}$.

Hoy nos resulta exótica gran parte de esta literatura que tuvo su apogeo en el barroco. Si a esto añadimos el sentido corporativo que desarrolló la Compañía de Jesús en su primer siglo de existencia comprenderemos el esplendor literario, artístico y estético que rigió las celebraciones fastuosas con ocasión de fechas de profundo significado religioso o patriótico, como eran las beatificaciones y canonizaciones de sus santos, las festividades de la Iglesia o los acontecimientos históricos. En la mayoría de esas oportunidades tanto los profesores como los alumnos capacitados hacían gala de su fecundidad literaria y creadora.

Mucha aceptación tuvieron los jeroglíficos, empresas o emblemas -que según Fernando R. de la Flor- eran conjuntos plástico-literarios, utilizados por las instituciones jesuíticas en las celebraciones que organizaban de todo tipo, sobre todo a lo largo del siglo XVII ${ }^{258}$. El jeroglífico significa una recuperación de ciertas formas simbólicas llevadas a cabo en el Renacimiento, las cuales fueron utilizadas en la arquitectura efímera al servicio de las fiestas religiosas con sus correspondientes adaptaciones en Espa$\tilde{n}^{259}$.

El pintor Antonio Palomino definía a comienzos del XVIII el jeroglífico como "una metáfora que incluye algún concepto doctrinal mediante un símbolo, o instrumento sin figura humana, con mote latino de autor clásico y versión poética en idioma vulgar" $^{260}$.

Y a continuación explicita el autor las funciones que desempeña el jeroglífico dentro de la arquitectura efímera:

"De éstos se usan en funerales de héroes y grandes capitanes; y en coronaciones de príncipes, entradas de reina y otras funciones semejantes; y asimismo en fiestas solemnes del Santísimo y de la Purísima Concepción, canonizaciones de san-

\footnotetext{
257 Ibíd. Regla, 18.

258 De la Flor, 1983: 262. Véase también del mismo autor 1982: 84-102. Para la cultura europea: Dimler, 1976: 85-106.

259 De la Flor, 1983: 262-263. Véase: Pedraza, 1978: 181-192. David, 1965.

260 Palomino, 1947: 106. Citado por De la Flor, 1983: 263.
} 
tos y otras festividades; en que se aplican figuras y símbolos de la Escritura Sagrada y otros conceptos teológicos, arcanos y misteriosos"261.

Si bien es verdad que algunas de estas actividades eran prohibitivas para un colegio pequeño, también es verdad que el lance poético y otro tipo de composiciones que sólo requieren del ingenio y la creatividad tuvieron que desarrollarse en las instituciones educativas venezolanas.

La vena poética, en latín y en castellano, fue habitual en la mayoría de los jesuitas neogranadinos. Bastará probar la afirmación con algunos ejemplos.

El primero pertenece al P. Juan Quintero, nacido en Gibraltar (Venezuela) y fallecido prematuramente en Bogotá el 12 de abril de 1693. Todavía muy joven su fácil versificación latina le llevó a ser elegido por el historiador P. Pedro de Mercado para que un epigrama suyo encabeza la Historia de la Provincia del Nuevo Reino y Quito de la Compañía de Jesús:

\section{Dum Regni primaeva Novi monumenta recludis}

Iesuadumque Deo gesta dicata refers:

Illi famosum Facundus reddis honorem,

hisque tuo calamo Fama perennis adesta.

Sic tibi mercaris miram, Mercate, coronam;

Quo argento? Libro mira docente tuo ${ }^{262}$.

Otro ejemplo lo encontramos en el P. Miguel de Monroy, rector del colegio de Mérida entre 1720 y 1724. Gracias al testimonio de José Ortiz y Morales sabemos que el P. Monroy lo visitó en 1710 y añade que el jesuita "tuvo noticia de mis estudios y de los cuatro tomos que tenía disponiendo de mi Arca evangélica y como de ingenio muy florido y en el poesía y latinidad tan versado, honró mis obras con los versos latinos siguientes, que por ser de mucha sutileza he querido con ellos coronar mi historia:

Non sic auratis Pactolus ridet arenis

Non sic Alcidis fulva catena trahit, Aureus ut stillus parefactaque litera servus

Allicit et vacuos mens opulenta replet.

Edidit Autor opes, opus hoc dum protulit orbi

Perlege. Nunc auri sacra putanda fames ${ }^{263}$.

\footnotetext{
261 Palomino, 1947: 106.
}

262 P. Ioannis Quintero bene in Auctorem affecti Epigramma. En: Mercado, 1957, I: 5. Su traducción es la siguiente: "Mientras manifiestas los comienzos dignos de recuerdo del Nuevo Reino, refieres las gestas consagradas a Dios de los jesuitas. Elocuente, rindes a aquel un célebre honor, y a éstos la fama perenne acompañará gracias a tu pluma. Así te compras, Mercado, una admirable corona. ¿Con qué dinero?. Enseñando cosas admirables con tu libro".

263 Biblioteca Nacional de Bogotá. Sección Manuscritos. Ortiz Morales. Observaciones curiosas y doctrinales que a hecho en su vida politica desde el dia 11 de febrero del año de 1658 en que nacio asta el dia en que las escribe con noticias de su buena fortuna y de sus desgracias ... a 11 de febrero de 1713. 
Como hasta el momento no hemos podido localizar ningún rastro de la producción literaria colegial venezolana apelaremos a algunos documentos similares redactados en la misma época en los colegios jesuíticos mexicanos.

Cualquier festividad o acontecimiento era propicio para la justa literaria en cualesquier de sus formas.

También los profesores entraban en lid en las competencias literarias que se debían desarrollarse sin cesar en el aula y en su entorno. Para mejor información nos remitimos al libro Osorio Romero donde el estudioso encontrará abundante literatura al respecto $^{264}$.

\section{El teatro}

Debemos subrayar la carencia de referencias en la documentación neogranadina que hasta el momento hemos consultado hacia un modelo practicado con pasión por los jesuitas durante el Barroco como es el teatro escolar. Sin embargo disponemos de algunas afirmaciones concretas que nos llevan a mantener una actitud de búsqueda.

Es necesario tener presente, como prueba de esta inquietud investigativa, que se conserva una pieza teatral del alumno bartolino Fernando Fernández de Valenzuela, titulada la Laurea crítica $^{265}$.

Además, nos consta que el Seminario de San Bartolomé se inauguró con una comedia latina que "se juzgó podía ser buena en la Corte" dice la Carta Annua ${ }^{266}$. Con posterioridad también el mismo colegio invirtió fuertes sumas en algunos actos dramáticos puestos en escena en junio de $1625^{267}$. Por testimonio de don José Ortiz Morales sabemos que para celebrar la canonización de San Francisco de Borja, en 1672, dispuso san Bartolomé de dos comedias: la primera se titulaba La Virtud al uso y de la segunda no nos ha quedado el título ${ }^{268}$.

Al parecer la actividad cultural de los estudios humanísticos pasó por momentos de gran intensidad. Por ejemplo, el 12 de enero de 1682 se veía precisado el Provincial, P. Juan Martínez Rubio, a recordar que "estando como estan doce pesos para pintura, y adorno del pergamino en las conclusiones de los de casa, no se permita excedan de esta cantidad en el gasto de colonias y botones, ni tampoco el que en el teatro se pongan

Fol., 190. Rivas Sacconi, 1977: 177-178. La traducción reza así: "No sonríe lo mismo el Pactolo con sus arenas de oro/ No atrae lo mismo la cadena áurea de Alcides/ Como tu estilo de oro y tu frase abierta/ hechiza a los hombres y tu mente poderosa sacia a los ignorantes./ El autor ha sacado a luz un tesoro./ Tu lee esta obra mientras la conoce el mundo./ Ahora sí que es verdad que hay que llamar sagrada el hambre de oro".

264 Biblioteca Nacional de México. Mss. 1600. Citado por Osorio Romero, 1969: 243-253.

265 Biblioteca Nacional de Colombia. Sección Manuscritos. Mss., 4. Arrom y Rivas Sacconi, 1960: 2027.

266 ARSI. N. R. et Q., 12. Historia. I. Carta annua de 1605, fol., 33v.

267 Archivo de San Bartolomé. Libro de gasto ordinario y extraordinario deste Collegio de San Bartolomé, fol., 123.

268 Ortiz Morales, 2004: 91. La forma como habla sobre este asunto indica que era normal el teatro entre los bartolinos.

153 José del Re Fajardo SJ. El colegio de San Francisco Javier de Mérida... 112-162. 
sillas sin licencia del Padre Rector, ni que se enciendan y quemen pebetes con riesgo de quemar las alfombras..."269.

Además, el análisis de los certámenes literarios así como las futuras investigaciones que se lleven a cabo sobre el teatro jesuítico neogranadino, al igual que el estudio de las biografías de estos abnegados maestros abrirán nuevas rutas para la reconstrucción de este importante medio cultural-educativo.

En Tunja fue objeto de quejas por parte de la familia de los PP. Francisco Ellauri y Juan y Martín de la Peña una pieza teatral ya que su vocación fue llevada a las tablas en el colegio de la capital boyacense ${ }^{270}$.

También del colegio de Cartagena hemos encontrado una pequeña alusión. El P. Alonso de Sandoval es amonestado por el General de la Orden "por permitir que, en una de las comedias que con fines didácticos se representaban en el colegio, salieran dos muchachos con ropa de mujeres",271.

Entre los papeles del archivo del colegio San Francisco Javier de Mérida inventariados en 1767 tan solo encontramos dos referencias al tema. El primero es una orden, de 1649, del Provincial del Nuevo Reino en que prohíbe a los jesuitas que asistan a "comedias y fandangos o bailes" ${ }^{272}$. El segundo hace relación a una Real Cédula que ordena que no se representen comedias en las iglesias ${ }^{273}$.

Asimismo queremos hacer alusión a un testimonio del jesuita bohemio Miguel Alejo Schabel quien nos ofrece un testimonio personal sobre lo vivido por él en Barinas a fines del siglo XVII:

... las comedias digo, en número de ocho, escogidas, decentes, en idioma español e impresas en España fueron representadas en el teatro erigido en la plaza de noche, con luces y lámparas. Algunas de ellas se podían exhibir en cualquiera ciudad europea muy dignamente ${ }^{274}$.

Ciertamente nos encontramos ante un hecho histórico que amerita una mejor investigación.

\section{La Academia}

La Academia, en la paideia jesuítica, se erigía como una pequeña entidad académico-social dentro de la propia institución educativa. Dado el reducido número de

269 APT. Fondo Astráin, 18. Ordenes antiguas, que por orden de N. R. P. Lorenzo Ricci, ya no están en uso y deven guardarse en el archivo. "Ordenes del Padre Juan Martinez Rubio Provincial desta Provincia del Nuevo Reyno y Quito, que dejó vissitando este Colegio de Santa Fe en 12 de Henero de 1682 años”, fol., $45-45 \mathrm{v}$.

270 ANB. Miscelánea, t. 69, fol., 332. Véase: Pacheco, 1959, I: 542-543.

271 Sandoval, 1987: 29-39.

272 AAM. Seminario. Caja, 1. Inventario de los papeles del archivo del Colegio San Francisco Javier, fol., 11.

273 Ibíd., fol., 11: "Yten. Una carta en que se hace relacion de una Cedula del Rey Nuestro Señor para que no se representen comedias en las Yglesias y que estas se cierren a puesta del sol, año de seiscientos sesenta y uno".

274 Schabel, 1965: 287. 
alumnos que siempre cobijó la mayoría de las instituciones educativas jesuíticas en el Nuevo Reino y Venezuela se podría pensar en la poca viabilidad de este ente para selectos. Por nuestra parte sospechamos que si existió porque generalmente iba hermanada con la Congregación Mariana ${ }^{275}$. En esencia constituía un llamado institucional a lo que hoy denominamos la excelencia y se reducía "un grupo de estudiosos escogido entre todos los escolares, que se reúnen bajo algún Prefecto de los Nuestros [jesuita], con objeto de tener especiales ejercicios relativos a los estudios" ${ }^{276}$.

En la práctica venía a ser un Seminario ya que su objetivo final consistía en profundizar en las materias que se estudiaban en el aula y debían llevarse a cabo los días de vacación $^{277}$.

Los "académicos" debían aventajar a los demás tanto en los estudios como en el ejemplo de su vida ${ }^{278}$. Se regían por sus autoridades propias y tenía como requisito imprescindible la asiduidad y el fervor en sus quehaceres ${ }^{279}$.

La temática fundamental giraba en torno a "todas aquellas cosas que suelen generar elocuencia o dimanar de ella" ${ }^{280}$. Pero la gama de posibilidades era extensísima: si se trataba de una declamación tomada de un orador o de un poeta debía seguir después "la crítica de los demás acerca de la voz, el gesto y de toda la declamación" ${ }^{281}$; también podía tratarse de redacciones propias escritas en los distintos géneros literarios ${ }^{282}$, o de análisis oratorios escritos "en estilo elegante" ${ }^{283}$; incluso se recomienda el simular procesos judiciales teniendo muy presentes las pruebas, los resortes psicológicos y demás lugares oratorios ${ }^{284}$.

Ciertamente la Academia bien llevada suponía la creación en sus miembros de una toma de conciencia frente a una microsociedad de la que se convertían en sus genuinos gestores mediante una más intensa comunicación, colaboración y responsabilidad tanto personal como colectiva.

Debemos confesar que tampoco en esta área hemos encontrado rastro alguno de documentación y en consecuencia abre la posibilidad a nuevas investigaciones que serían de gran utilidad para la historia de la pedagogía en la antigua Nueva Granada.

Estos son, a grandes trazos, los componentes de la educación y formación que día a día impartieron los jesuitas en sus colegios dispersos en la amplia geografía neogranadina.

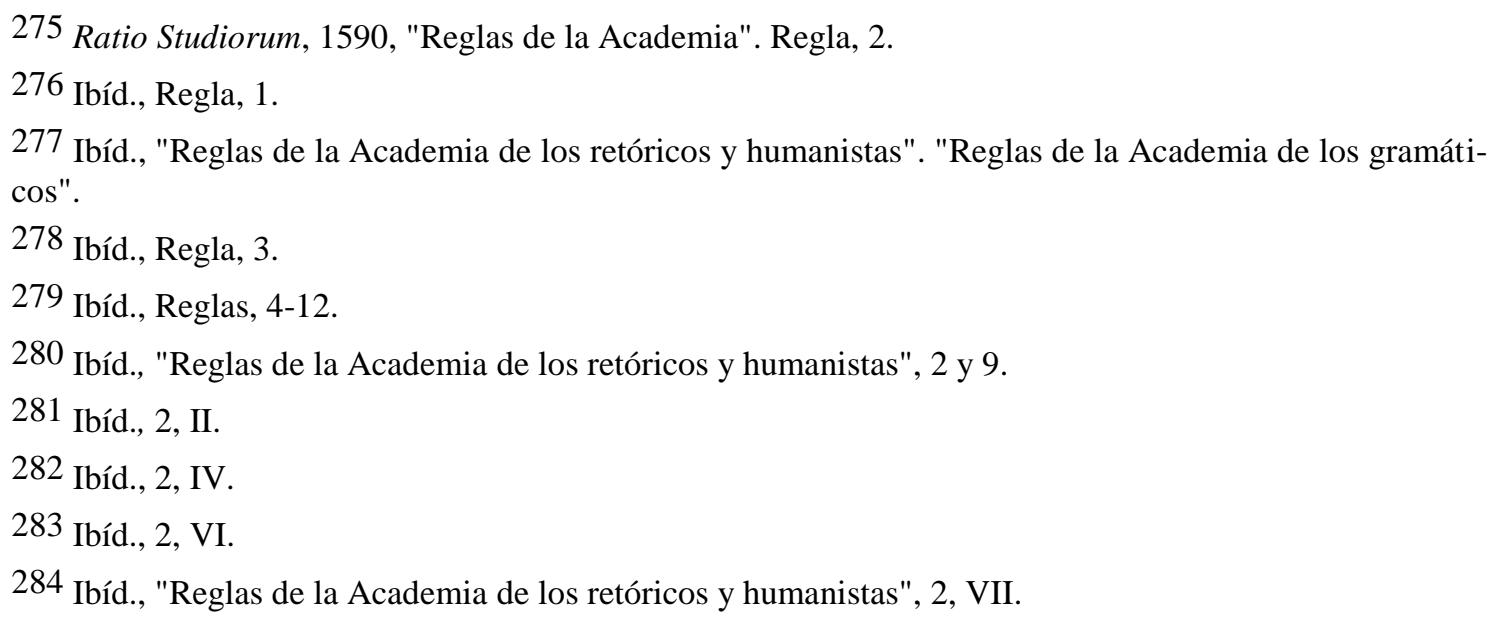


Pero en 1767 este gran proyecto educativo fue suprimido de raíz. La magnitud de la catástrofe que provocó la Pragmática Sanción firmada por Carlos III el 2 de abril de 1767 se puede medir en términos cuantitativos en lo que fue la Provincia del Nuevo Reino y Quito fundada en 1611 y dividida en 1696.

De repente dejaron de funcionar 5 universidades: Panamá, Bogotá, Popayán, Quito y Santo Domingo. A esa clausura se sumaron 22 colegios: 11 en la zona neogranadina (Cartagena, Mompox, Honda, Antioquia, Bogotá, Tunja, Pamplona, Mérida, Maracaibo, Caracas y Santo Domingo) y otros 11 en la quiteña (Latacunga, Ríobamba, Cuenca, Loja, Ibarra, Ambato, Quito, Panamá, Popayán, Pasto y Buga).

\section{Fuentes documentales}

AAM. Archivo Arquidiocesano. Mérida. Seminario. Caja, 1.

AGI. Archivo General de Indias. Sevilla. Contatación, 5548, 5549.

AHN. Archivo Histórico Nacional. Madrid. Jesuitas, 827/2.

ANB. Archivo Nacional de Colombia. Bogotá. Miscelánea, 69 y Temporalidades, 18,

APT. Archivo de la Provincia de Toledo. Alcalá de Henares. Fondo Astráin, 18,

ARSI. Archivum Romanum Societas Iesu. Roma. Institutum, 40 y Provincia Novi Regni et Quiti (N. R. et Q.) 12-I,

Biblioteca Nacional de Colombia. Bogotá. Sección Manuscritos. Mss., 4, 17.

Biblioteca Nacional de México. México. Mss. 1600.

\section{Referencias}

Alfaro, A. (2003). "Hombres paradójicos. La experiencia de la alteridad". Misiones jesuitas. Artes de México. México, 65: 8-27.

Arrom J. J. y Rivas Sacconi, J. M. (1960). La "Laurea Crítica” de Fernando Fernández de Valenzuela, primera obra teatral colombiana. Bogotá: Instituto Caro y Cuervo.

Baldini, H. (2000). Saggi sulla cultura della Compagnia di Gesù. Padua: CLEUP Editrice.

Barthes, R. (1974). Investigaciones retóricas. I. La antigua retórica. Buenos Aires: Tiempo Nuevo.

Bartolomé Martínez, B. (1982). "Las cátedras de gramática de los jesuitas en las universidades de Aragón". Hispania Sacra, 34: 389-448.

Batllori, M. (1993). "San Ignacio y la fundación de los jesuitas". "La pedagogía de la Ratio Studiorum". En: Delgado Criado, B. (Ed.). Historia de la Educación en España y América. II. La educación en la España moderna (Siglos XVI-XVIII). Madrid: Fundación Santa María: 57-74. 
(1988). "Presencia de España en la Europa del siglo XVIII". En: Historia de España. Tomo XXXI. La época de la ilustración. Vol., I: El Estado y la cultura (1759-1808). Madrid: Espasa-Calpe: IX-XL.

(1958). Gracián y el Barroco. Roma: Edizioni di Storia e Letteratura.

(1966). La cultura hispano-italiana de los jesuitas expulsos. Españoleshispanoamericanos-filipinos. Madrid: Editorial Gredos.

Borromeo, A. S/f [1991]. "Ignacio de Loyola y su obra a la luz de las más recientes tendencias historiográficas”. En: Aldea, Q. (Ed.). Ignacio de Loyola en la gran crisis del siglo XVI. Bilbao, Universidad Complutense-Mensajero-Sal Terrae: 321334.

Bremond, H. (1916). Histoire littéraire su sentiment religieux en France. París: Bloud y Gay Editeurs.

Briceño Jáuregi, M. (1991). "La prelección como elemento metodológico en la enseñanza de las humanidades en los colegios jesuíticos neogranadinos (s. XVIIXVIII)". En: Del Rey Fajardo, J. (Ed.). La pedagogía jesuítica en Venezuela. San Cristóbal, Universidad Católica del Táchira, II: 589-698.

Casanovas, I. (1932). Joseph Finestres. Estudis biografics. Barcelona: Biblioteca Balmes.

Certau, M. de (1974). "Le 17e. siècle français". En: Derville, A. "Jesuites". En: Viller, M. (et. al.). Dictionnaire de spiritualité ascétique et mystique, doctrine et histoire. París, VIII: 994-1015.

Charmot, F. (1934). L'Humanisme et l'humain. Psychologie individuelle et sociale. París: Editions Spes.

(1952). La pedagogía de los jesuitas. Madrid: Sapientia.

Codina Mir, G. (1968). Aux sources de la pédagogie des Jésuites. Le "Modus parisiensis". Romae: Institutum Historicum Societatis Jesu.

Codorniu, A. (1764). Desagravio de los autores que ofende el Barbadiño. Barcelona: en la Imprenta de Maria Angela Marti viuda..., 1764.

Colmenares, G. (1969). Las haciendas de los jesuitas en el Nuevo Reino de Granada. Siglo XVIII. Bogotá: Universidad Nacional de Colombia.

Constitutiones Societatis Iesu et Epitome Instituti. (1943). Romae: Apud Curiam Praepositi Generalis.

Dainville, F. de (1978). L'Education des Jésuites. Paris: Editions de Minuit.

David, M. V. (1965). Le débat sur les écritures et l"hieroglyfe au XVIIe et XVIIIe siècles. París: Presses Universitaires de France.

De la Flor, F. R. (1982). "El jeroglífico y la arquitectura efímera del Barroco". Boletín del Museo e Instituto Camón Aznar. Madrid, 8: 84-102.

(1983). "Picta poesis. Un sermón en jeroglíficos, dedicado por Alonso de Ledesma a las fiestas de Beatificación de San Ignacio, en 1610". En: Archivum Historicum Societatis Jesu. Romae, anno LII, fasc. 104: 262-274. 
Del Rey Fajardo, J. et. al. (1995). Virtud, letras y política en la Mérida colonial. San Cristóbal: Universidad Católica.

Del Rey Fajardo, J. y Marquínez Argotr, G. (2004). Breve tratado del cielo y los astros del M. Javeriano Mateo Mimbela (1663-1736). Bogotá: Pontificia Universidad Javeriana.

Del Rey Fajardo, J. (2002). Catedráticos jesuitas de la Javeriana colonial. Bogotá: Pontificia Universidad Javeriana.

s/f [2001]. La biblioteca colonial de la Universidad Javeriana de Bogotá. Santafé de Bogotá-San Cristóbal: Universidad Católica del Táchira.

(1990). La expulsión de los Jesuitas de Venezuela. San Cristóbal: Universidad Católica del Táchira.

(2010). La Facultad de Lenguas de la Universidad Javeriana colonial y la República de las Letras neograndinas. Bogotá: Editorial El Búho.

(1991). La pedagogía jesuítica en Venezuela, 1628-1767. San Cristóbal, Universidad Católica del Táchira, II: 245-420.

Delumeau, J. (1979). Le catholicisme entre Luther et Voltaire. París: Presses Universitaires de France.

Demoustier, A. y Julia, D. (1997). Ratio Studiorum. Plan raisonné et institution des études dans la Compagnie de Jésus: Paris, Belin.

Demoustier, A. (1997). "Les jesuites et l'enseignement à la fin du XVIe siècle". En: Demoustier, A. y Julia, D. Ratio Studiorum. Plan raisonné et institution des études dans la Compagnie de Jésus: Paris, Belin: 12-28.

Dimler, G. R. (1976). "The Egg as Emblem: Genesis and Structure of a Jesuit Emblem Book". Studies in Iconography, 2: 85-106.

Escalera, J. (2001). “Colegio Imperial de Madrid”. En: O`Neill, C. E. y Domínguez, J. M. Diccionario histórico de la Compañía de Jesús. Roma-Madrid, I: 844.

Feingold, M. (Ed) (2003). Jesuit Science and the Republic of Letters. Cambridge, Mass. MIT Press.

Gerbi, A. (1982). La disputa del Nuevo Mundo. Historia de una polémica 1750-1900. México: Fondo de Cultura Económica.

Giard, L. y Vaucelles, L. de (1996). Les Jésuites à l'âge barroque (1540-1640). Grenoble, Jerôme Millon.

Giard, L. (1995). "Le devoir d'intelligence ou l'insertion des jésuites dans le monde du savoir". En: Giard, L. (Dir.). Les jésuites à la Renaissance. Système éducatif et production du savoir. Paris : Presses Universitaires de France: XI-LXXIX.

(2003). "Los primeros tiempos de la Compañía de Jesús: el proyecto inicial al ingreso en la enseñanza". En: Dumortier, F. X., et. al. Tradición jesuita. Enseñanza, espiritualidad, misión. Montevideo: Presses Universitaires de Namur-Ausjal-Universidad Católica: 11-44.

Gilij, F. S. (1954). Ensayo de Historia Americana. Bogotá: Academia Colombiana de Historia, IV. 
González Cruz, F. (2001). Globalización y Lugarización. La Quebrada: Universidad Valle del Momboy y Centro de Estudios Provinciales y Locales.

Hellyer, M. (2005). Catholic Physics: Jesuit Natural Philosophy in Early Modern Germany. Notre Dame: Ind. University of Notre Dame Press.

Herman, J-B. (1914). La pédagogie des jésuites au XVI siècle. Louvain-Bruxelles-Paris: Bureau du Recueil.

Julián, I. (1979). "Lo mejor de la vida, Religión, Doctrina y Sangre recogido en un noble joven colegial de el Real, Mayor y Seminario Colegio de San Bartholome, propuesto en Ynstruccion Christiano-Politica para el uso de dicho Colegio a quien lo dedica vn Estudiante Theologo de la Compañia de Jesús en su segundo año a suplicas de la misma juventud, noble". La primera edición impresa apareció en: Del Rey Fajardo, J. La pedagogía jesuítica en la Venezuela hispánica. Caracas, Biblioteca de la Academia Nacional de la Historia, vol., 138: 325-427.

Juventius [Jouvancy, J. de] (1703). Magistris Scholarum inferiorum Societatis Iesu de ratione discendi et docendi ex decreto Congregat. Generalis XIV. Florencia: Apud Michaelem Nestenium. [Traducción castellana: Juvencio, J. (1979). "Método para aprender y para enseñar". Florencia, 1703. En: Del rey Fajardo, J. La pedagogía jesuítica en la Venezuela hispánica. Caracas, Academia Nacional de la Historia: 639-752].

Lacouture, J. (1993). Jesuitas. I. Los conquistadores. Barcelona-Buenos Aires-México: Ediciones Paidís.

Lange Cruz, I. (2005). Carisma ignaciano y mística de la educación. Madrid: Universidad Pontificia de Comillas.

Le Gaudier, A. (1643). De natura et statibus perfectionis. Opus posthumum: Parisiis, Cramoisy.

Leturia, P. (1940). "Perché la Compagnia de Gesù divenne un Ordine insegnante". En: Gregorianum. Roma, 21: 350-382.

Luckas, L. (1961). De origine collegiorum externorum deque controversiis circa eorum paupertatem obortis 1539-1608. Romae: Institutum Historicum S.I.

Monumenta Paedagogica Societatis Iesu. Roma, Monumenta Historica Societatis Iesu, I, 1540-1556 (1965); II, 1557-1572 (Roma, 1974); III, 15571572 (Roma, 1974); IV, 1573-1580 (Roma, 1981); V, 1586, 1591, 1599 (Roma, 1986); VI, 1582-1587 (Roma, 1986); VII, 1588-1616 (Roma, 1992).

Méndez Plancarte, G. (Ed.) (1962). Humanistas del siglo XVIII. Introducción y selección: Gabriel Méndez Plancarte. México: Universidad Nacional Autónoma de México.

Mercado, P. de (1957). Historia de la Provincia del Nuevo Reino y Quito de la Compañía de Jesús. Bogotá: Biblioteca de la Presidencia de Colombia.

(1676). Práctica de los ministerios eclesiásticos. Compuesto por el Padre Pedro de Mercado de la Compañía de Jesús. Sevilla: por Juan de Osuna.

Minardi, S. (2006). “De misiones”. En: El Nacional. (Papel Literario). Caracas, sábado 15 de julio. 
Morner, M. (1955). The Political and Economic Activities of the Jesuits in the La Plata Region: The Aubsburg era. Estocolmo.

O’Malley, J. et. al. (2002). The Jesuits II: Cultures, Sciences, and the Arts, 1540-1773, Toronto: University of Toronto Press.

(1999). The Jesuits: Cultures, Sciences, and the Arts, 1540-1773, Toronto: University of Toronto Press.

(2007). "Cinco misiones del carisma jesuita. Contenido y método". En: Apuntes ignacianos. Bogotá, 51: 4-38.

(2005). "Saint Ignatious and the Cultural Mission of the Society of Jesus”. En: O’Malley, J. y Bailey, G. A. (Ed.). The Jesuits and the Arts, 15401773. Philadelphia: Saint Joseph's University Press: 3-16.

O’Neill, C. E. (2001). “Humanismo”. En: O’Neill, C. E. y Domínguez, J. M. Diccionario histórico de la Compañía de Jesús. Roma-Madrid, II: 1967-1971.

Olmedo, F. [González] (1949). "Humanismo". Miscelánea Comillense. Santander: 4353.

Ortiz y Morales, J. (1713). Observaciones curiosas y doctrinales que a hecho en su vida politica desde el dia 11 de febrero del año de 1658 en que nacio asta el dia en que las escribe con noticias de su buena fortuna y de sus desgracias ... a 11 de febrero de 1713. [Biblioteca Nacional de Bogotá. Sección Manuscritos, Mss. 130].

Osorio Romero, I. (1979). Colegios y profesores jesuitas que enseñaron latín en Nueva España (1572-1767). México: Universidad Nacional Autónoma de México.

(1980). Floresta de gramática, poética y retórica en Nueva España (1521-1767). México: Universidad Nacional Autónoma de México.

Pacheco, J. M. (1991). "La Universidad Javeriana de Santafé de Bogotá durante la época colonial”. En: Del Rey Fajardo, J. (Ed.). La pedagogía jesuítica en Venezuela 1628-1767. San Cristóbal, Universidad Católica del Táchira, I: 77-173.

Los jesuitas en Colombia. Bogotá, Editorial San Juan Eudes, I, 1959; Hijos de Santiago Rodríguez, II, 1962; Pontificia Universidad Javeriana, III, 1989.

Pachtler, M. (1600-1772). Ratio Studiorum et Institutiones Scholasticae Societatis Jesu per Germaniam olim vigentes collectae concinnatae dilucidatae a G. M. Pachtler S. J. Volumen III: Ordinationes Generalium et ordo Studiorum generalium ab anno 1600, ad annum 1772. Hemos utilizado la reproducción aparecida en Osnabrück en 1968 en la Biblio-Verlag. 4 vols

Palomino, A. (1947). Museo pictórico y escala óptica. Madrid: Aguilar.

Pedraza, P. (1978). "Breves notas sobre la cultura emblemática barroca". Saitabi. Valencia, 28: 181-192.

Peralta, C. (1984). "Gracián, entre Barroco y Neoclásico en la Agudeza". Paramillo. San Cristóbal, 2-3: 543-554. 
Posevino, A. (1593). De cultura ingeniorum. Forma parte del libro: Bibliotheca selecta qua agitur de ratione studiorum in Historia, in Disciplinis, in salute omnium procuranda. Romae: Ex Typorgr. Apostolica Vaticana.

Ratio Atque Institutio (1599). Studiorum Societatis Jesu. Superiorum Permissu. Neapoli, apud Tarquinium Longhum.

Regulae Societatis Jesu (1590). Romae: In Collegio eiusdem Societatis.

Reinhard, W. (1977). "Gegenreformation als Modernisierung? Prolegomena zu einer Theorie des konfessionellen Zeitalters". Archiv für Reformationsgeschichte, 68: 226-252. Reinhard, W. (1981). "Konfession und Konfessionalissierung in Europa". En: Reinhard, W. Bekentniss und Geschichte: die Confessio Augustana im historischen Zusammenhang. Ringvorlesung der Universität Augsburg im Jubiläumsjahr 1980. München: Vögel: 165-189.

Richeome, L. (1614). "L'académie d'honneur dressé par le Fils de Dieux au royaume de son Eglise”. En Oeuvres. París, 2 (1628)

Rivas Sacconi, J. M. (1949). El Latín en Colombia. Bogotá: Publicaciones del Instituto Caro y Cuervo, $\mathrm{n}^{\circ} .3$.

(1977). El Latín en Colombia. Bosquejo histórico del humanismo colombiano. Bogotá: Instituto Colombiano de Cultura.

Romano, A. (1999). La Contre-Réforme mathématique: Constitution et diffusion d'une culture mathématique jésuite à la Renaisance. Roma: École française de Rome.

Samudio, E., Del Rey Fajardo, J. y Briceño Jáuregui, M. (2003). El Colegio San Francisco Javier en la Mérida colonial, germen histórico de la Universidad de los Andes. Mérida: Universidad de los Andes, 8 tomos.

Samudio, E. (1985). Las haciendas del colegio San Francisco Javier de la Compañía de Jesús en Mérida. 1628-1767. Mérida: Universidad de los Andes.

Sandoval, A. de (1987). Un tratado sobre la esclavitud. Introducción, transcripción y traducción de Enriqueta Vila Vilar. Madrid: Alianza Editorial.

Schabel, M. A. (1965). "Noticias de América que manda el Padre Miguel Alejo Schabel, misionero de la Sociedad [Compañía] de Jesús al muy Reverendo Padre Miguel Angel Tamburino [Tamburini] Prepósito y Vicario General de la misma Sociedad, el 9 de abril del año 1705, de la nueva misión en las islas de Curazao, Bonaire, Aruba y del río Apure en la Tierra Firme india en el Reino de la Nueva Granada". Anuario del Instituto de Antropología e Historia. Caracas, Universidad Central de Venezuela, II: 269-306.

Schulze, W. (1987). "Gerhard Öestereichs Begriff <Sozialidisziplinierung $>$ in der frühen Neuzeit”. Zeitschrift für hitorische Forschung, 14: 265-302.

Sievernich, M. y Switek, G. (Ed.). Ignatianisch. Eigenart un Methode der Gesellschaft Jesu. Freiburg-Basel-Wien: Verlag Herder.

Sievernich, M. (2005). “La Misión de la Compañía de Jesús: inculturación y proceso". En: Hernández Palomo, J. J. y Moreno Jeria R. (Coord.). La Misión y los jesuitas en la América española, 1566-1767. Sevilla: Consejo Superior de Investigaciones Científicas-Escuela de Estudios Hispano-Americanos: 265-287. 
Sommervogel, C. (1960). Bibliothèque de la Compagnie de Jésus. [Reimpresión por el P. M. Dykmans. Héverlé-Louvain. Éditions de la Bibliothèque S. J. Collège philosophique et théologique].

Springetti, Emilio (1962). "Storia e fortuna della grammatica di Emmanuele Alvares S.J.". Humanitas. Coimbra, vols., XIII-XIV: 283-304.

Uriarte, J. E. de (1904-1916). Catálogo razonado de obras anónimas y seudónimas de autores de la Compañía de Jesús pertenecientes a la antigua asistencia españo$l a$ : con un apéndice de otras de los mismos, dignas de especial estudio bibliográfico... Madrid: Sucesores de Rivadeneyra, 5 vols.

Uslar Pietri, A. (1970). “Cómo se aprende a ser hombre”. El Tiempo. Bogotá, 25 de marzo.

Vives, J. J. (1535), Declamationes Syllanae, Burgos. 